University of Nebraska - Lincoln

DigitalCommons@University of Nebraska - Lincoln

1991

\title{
The Pangaean Megamonsoon- Evidence from the Upper Triassic Chinle Formation, Colorado Plateau
}

\author{
Russell F. Dubiel \\ U.S. Geological Survey \\ Judith Totman Parrish \\ University of Arizona \\ J. Michael Parrish \\ Northern Illinois University \\ Steven C. Good \\ University of Colorado
}

Follow this and additional works at: https://digitalcommons.unl.edu/usgsstaffpub

Part of the Earth Sciences Commons

Dubiel, Russell F.; Parrish, Judith Totman; Parrish, J. Michael; and Good, Steven C., "The Pangaean Megamonsoon- Evidence from the Upper Triassic Chinle Formation, Colorado Plateau" (1991). USGS Staff -- Published Research. 218.

https://digitalcommons.unl.edu/usgsstaffpub/218

This Article is brought to you for free and open access by the US Geological Survey at DigitalCommons@University of Nebraska - Lincoln. It has been accepted for inclusion in USGS Staff -- Published Research by an authorized administrator of DigitalCommons@University of Nebraska - Lincoln. 


\title{
The Pangaean Megamonsoon- Evidence from the Upper Triassic Chinle Formation, Colorado Plateau
}

\author{
RUSSELL F. DUBIEL \\ U.S. Geological Survey, MS 919, Box 25046, DFC, Denver, CO 80225 \\ JUDITH TOTMAN PARRISH \\ Department of Geosciences, University of Arizona, Tucson, AZ 85721 \\ J. MICHAEL PARRISH
}

Department of Biological Sciences, Northern Illinois University, DeKalb, IL 60115

STEVEN C. GOOD

Department of Geological Sciences, University of Colorado, Boulder, CO 80309

PALAIOS, 1991, V. 6, p. 347-370

The Upper Triassic Chinle Formation was deposited at an exceptional time in Earth's paleogeographic and paleoclimatic history. During the Triassic, the supercontinent Pangaea was at its greatest size, in terms of both aggregated continental crust and exposed land area. Moreover, the exposed land was divided symmetrically about the paleoequator between the northern and southern hemispheres. These conditions were ideal for maximizing monsoonal circulation, as predicted from paleoclimate models. The Chinle was deposited between about $5^{\circ}$ to $15^{\circ} \mathrm{N}$ paleolatitude in the western equatorial region of Pangaea, a key area for documenting the effects of the monsoonal climate. This study summarizes sedimentologic and paleontologic data from the Chinle Formation on the Colorado Plateau and integrates that data with paleoclimatic models. The evidence for abundant moisture and seasonality attest to the reversal of equatorial flow and support the hypothesis that the Triassic Pangaean climate was dominated by monsoonal circulation.

The Chinle Formation contains continental lithofacies deposited in fluvial channels, crevasse splays, lakes, bogs, marshes, and lacustrine deltas that reflect abundant precipitation and shallow water tables. Paleosols and ichnofossils indicate that water tables and lake levels fluc- tuated episodically. Interbedded lacustrine carbonates and marginal-lacustrine siltstones and mudstones indicate longer-term but regular, episodic fluctuations in lake level. Fine-scale laminations in lacustrine carbonates suggest a seasonal influx of clastic sediment, and thus precipitation, to the basin. Uppermost Chinle strata consist of lacustrine and marginal-lacustrine mudstones interbedded with minor eolian sand sheets and eolian dunes; thus, the later Triassic reflects continued precipitation, but was marked by more pronounced and extended dry seasons.

The Chinle fossil record corroborates the paleoclimatic interpretation based on sedimentologic data. The flora is consistent with moist, rather humid conditions, at least in the vicinity of fluvial channels and ponds, where most of the known plants were preserved by rapid sedimentation and burial below the water table. Invertebrates include fluvial and lacustrine unionid bivalves, gastropods, conchostracans, and ostracodes. Widespread occurrence of large unionids indicates perennial streams and lakes. Freshwater bivalves and gastropods provide evidence for seasonal climates on the basis of their ecological requirements, taphonomic occurrences, and growth banding preserved within unionid bivalve shells. A wide variety of actinopterygian fish are present, as well as isolated taxa of hybodont sharks, dipnoans, and coelacanths. The large coelacanths require the presence of 


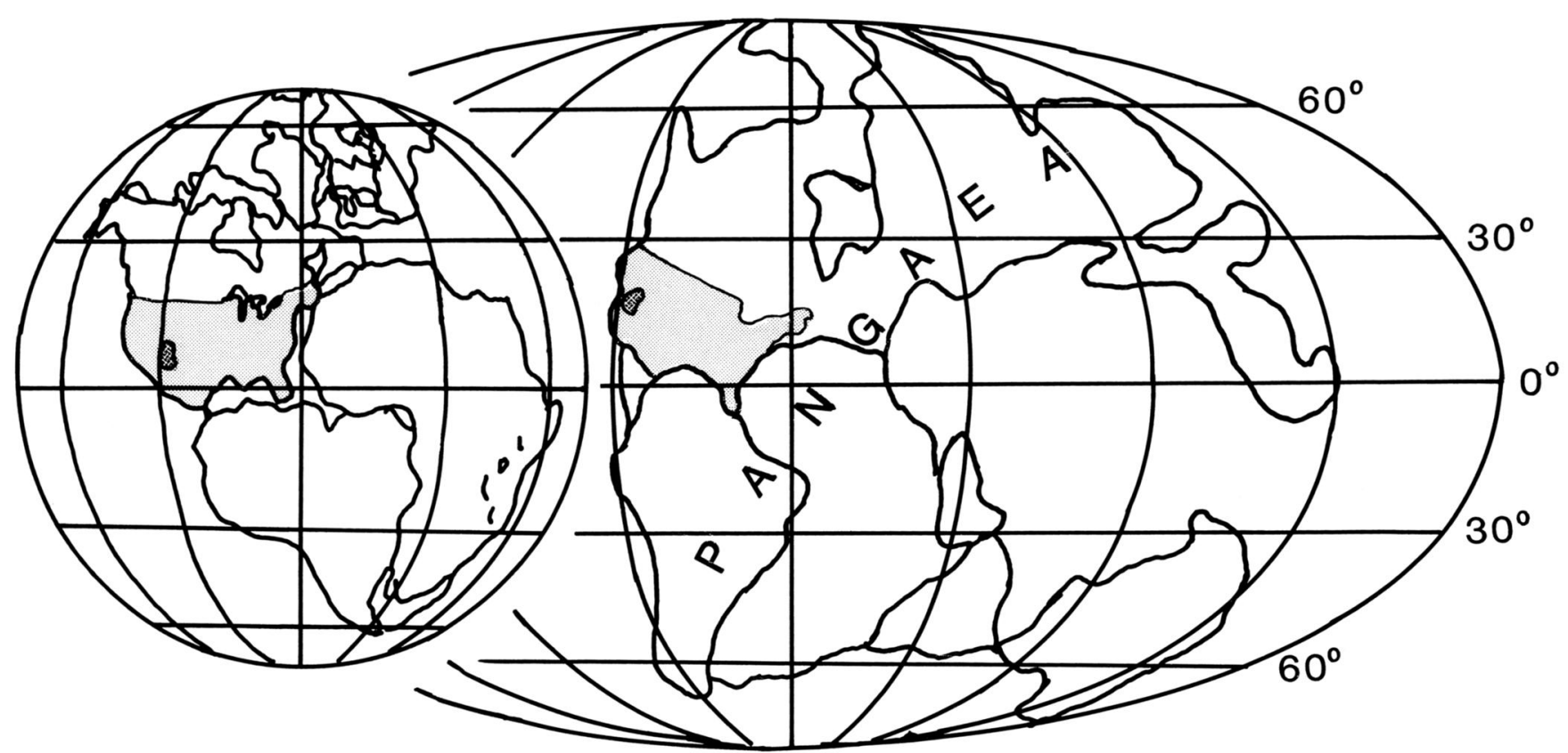

FIGURE 1-Schematic reconstruction of Pangaea showing the approximate location of the Colorado Plateau (dark shading) and the United States (light shading) for reference. Modified from reconstruction of Induan (earliest Triassic) paleogeography by Ziegler et al. (1983). Inset: partial reconstruction of Pangaea for the Late Triassic (data from Owl Rock Member of the Chinle Formation; Bazard and Butler, in press).

perennial fluvial and/or lacustrine systems. The tetrapod fauna is dominated by aquatic forms, notably metoposaurid amphibians, and phytosaurian archosaurs; terrestrial archosaurs and synapsids are more poorly represented quantitatively. Vertebrate taphonomy and the nature of skeletal preservation also provide evidence of seasonality during Chinle deposition.

\section{INTRODUCTION}

The supercontinent Pangaea represented an exceptional phase in Earth's paleogeographic history, a maximum of continental aggregation (Valentine and Moores, 1970) that began in the Carboniferous with the collision of Laurussia and Gondwana and culminated in the Triassic with the addition of Kazakhstan, Siberia, and parts of China and southeastern Asia (Smith et al., 1973; Smith and Briden, 1977; McElhinny et al., 1981; Klimetz, 1983, fig. 4; Ziegler et al., 1983; Veevers, 1988). In the Triassic, exposed land extended from about $85^{\circ} \mathrm{N}$ to $90^{\circ} \mathrm{S}$ (Ziegler et al., 1983). Sea level was low through much of what might be called the "peak" Pangaean interval, the Permian and Triassic (Vail et al., 1977), and the area of exposed land was great (Parrish, 1985). More importantly, with the exception of a small fraction in parts of what is now China and southeast Asia, this exposed land area constituted a single continent (Fig. 1). On first principles, it would be expected that the continent would have had an extraordinary effect on global paleoclimate. The continent cut across and therefore disrupted nearly every part of the zonal atmospheric circu- lation. In addition, the great size of the exposed land, the presence of large landmasses in low mid-latitudes, and the presence of a warm seaway to act as a source of moisture would have maximized summer heating in the circumTethyan part of the continent.

The Permian-Triassic interval has long been regarded as unusual, representing a unique and extreme paleoclimatic state, because red beds and evaporites were global in extent (Schwarzbach, 1963; Waugh, 1973; Turner, 1980; Glennie, 1987; and many others) and because evaporite depositional regimes covered more area in the Triassic than at any other time (Gordon, 1975). As data on paleoclimatically significant fossils and rocks have gradually been accumulated and put into the context of plate tectonics, the uniqueness of the Permian-Triassic has only been emphasized.

In a landmark work linking the then-new concept of polar wandering/continental drift and paleoclimate, Briden and Irving (1964) compared the modern and paleolatitudinal distributions of climatically significant rocks. Briden and Irving (1964) started with the assumption that the distributions of climatically controlled sediments were similar in the past to their distributions today, that is, that the general zonal pattern characteristic of much of modern circulation and climate would have existed throughout Earth history. With this assumption, and despite the fact that their continental reconstructions were crude by current standards, the distributions of most rock types, particularly carbonates, made more sense when plotted against paleolatitude than against present latitude.

Unlike carbonates, however, the distribution of evapo- 
rites and eolian sandstones was not clarified by plotting data on paleolatitudinal reconstructions (Briden and Irving, 1964). Modern evaporites and sand seas tend to occur in the "dry belts" centered on $30^{\circ}$ north and south (Borchert and Muir, 1964; McKee, 1979). Plotted against modern latitudes, their ancient counterparts showed a similar distribution. However, plotted against paleolatitude, evaporites and eolian sandstones clustered near the equator (Briden and Irving, 1964; Ziegler et al., 1979; Parrish et al., 1982). A breakdown of the data by time revealed that Mesozoic and Cenozoic deposits plotted where expected when restored to their paleolatitudes but that Paleozoic deposits, particularly those of the upper Paleozoic, did not. Parrish et al. (1982) showed further that the upper Paleozoic pattern extended into the lower Mesozoic. Although Briden and Irving (1964) were using the paleoclimatic data as a test of the paleomagnetic data, they did not change their continental reconstructions based on the discrepancy between the two data sets. First, they had no reason to regard the paleomagnetic data from upper Paleozoic rocks as systematically less reliable than data from older and younger rocks. Second, no adjustment of the continental positions could be made that would satisfy both the zonal climatic patterns and the known plate positions. Briden and Irving (1964) recognized, instead, that the anomaly might have been due to some unusual climatic process.

Robinson (1973) was the first to explicitly describe the climate of Pangaea as monsoonal, basing her description on the global distribution of red beds, evaporites, and coals in Triassic rocks. She confirmed Briden and Irving's (1964) finding that these paleoclimatically significant rocks are not distributed in simple latitudinal zones, and also found that the rocks formed an odd geographic mixture. Although this mixture was at least partly an artifact of plotting data for the entire period on one map, the deposits nevertheless suggested to Robinson (1973) that the climate was strongly seasonal, and she used the term monsoon to describe it. The same concept has appeared repeatedly in different forms. Daugherty (1941), for example, described the flora and environment of the Chinle Formation as "savanna," a term he used to compare the wet-dry climatic signature of the ancient ecosystem to modern savannas (although the comparison is not entirely realistic since modern savanna ecosystems are dominated by grasses, which evolved much later than the Triassic). Much of the present Earth's savanna occurs within the region of influence of the Asian monsoon (Rumney, 1968; Espenshade and Morrison, 1978) and always in areas of strongly seasonal rainfall. Since Robinson's (1973) work, the beginnings of a theoretical basis for the hypothesis of Pangaean monsoonal circulation have been established in a series of papers outlining the general hypothesis (Parrish et al., 1982, 1986), the development of the monsoon (Rowley et al., 1985), the monsoonal maximum (Parrish and Peterson, 1988), and the breakdown of the monsoon (Parrish and Doyle, 1984). Recent numerical climate experiments using Pangaean geography (Crowley et al., 1989; Kutzbach and Gallimore, 1989) also indicated a monsoonal climate.

Because the Chinle Formation was deposited in the western equatorial region of Pangaea where the effects of tropical monsoonal circulation should be pronounced, the Chinle is a key unit for understanding the dynamics of the Pangaean monsoon. Although a general consensus exists on the interpretation of the continental depositional environments and depositional history of the Chinle Formation, numerous disparate inferences have been drawn regarding the climate during Chinle deposition based on various paleontologic and sedimentologic criteria. Paleobotanists, for example, have provided several incongruous interpretations of Chinle climate. Ash (1967, 1972, 1978) and Ash and Creber (1990) argued for a tropical, humid climate, possibly with increasing aridity in the upper parts of the Chinle. Daugherty (1941) interpreted the climate as humid subtropical to tropical with ample rainfall and a distinct dry season. Gottesfeld (1972) suggested the climate was warm and arid, perhaps seasonal, with throughflowing streams and increasing aridity towards the top of the formation. Thus, the interpretations have ranged from ever-wet to predominantly arid.

We begin by discussing the dynamics of monsoonal systems as understood principally from the modern Asian monsoon, the strongest such system at present. This is followed by a discussion of the climatic patterns that are predicted for Pangaea based on our current understanding of monsoon dynamics, concentrating on the western equatorial region, where the Chinle Formation was deposited. We show that the climatic patterns expected in that region were likely to have been controlled by the global circulation system. Interpretations of the climatically significant sedimentological and paleontological evidence from the Chinle are then presented, followed by a discussion of the Chinle in the global climatic context.

Documentation of the geologic evidence for Pangaean paleoclimate is extensive, as implied by the references cited above, but it is scattered; integration of available evidence worldwide is underway (Parrish, 1988). However, full characterization of the monsoonal system requires more detail than is readily achievable on a global scale, and the global documentation must necessarily be accompanied by detailed studies directed toward key intervals and regions. As a result of the dynamics of the Pangaean monsoon, the western equatorial portion of Pangaea is such a region.

\section{MONSOONAL CIRCULATION AND CLIMATE AND THE PANGAEAN MONSOON}

Although the term "monsoon" sometimes is used by geologists interchangeably with "season," to climatologists the term refers to a climate system that is distinct from seasonality as expressed in most regions of the world. An important feature of monsoonal circulation is cross-equatorial flow, which results from the thermal and pressure contrast between the winter and summer hemispheres. A monsoon system is driven primarily by sensible heating, so it necessarily involves circulation in the tropics and subtropics. The climatic consequences of monsoonal flow are 1) abundant, but extremely seasonal, rainfall, concentrated in the summer months, and 2) little annual tem- 


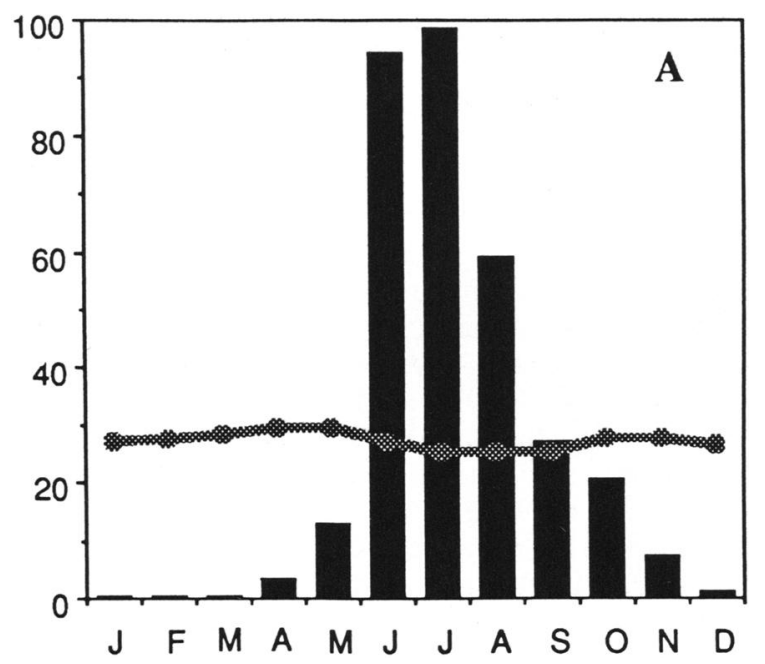

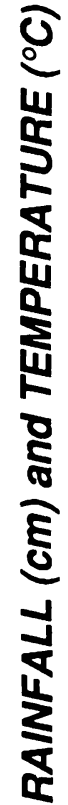
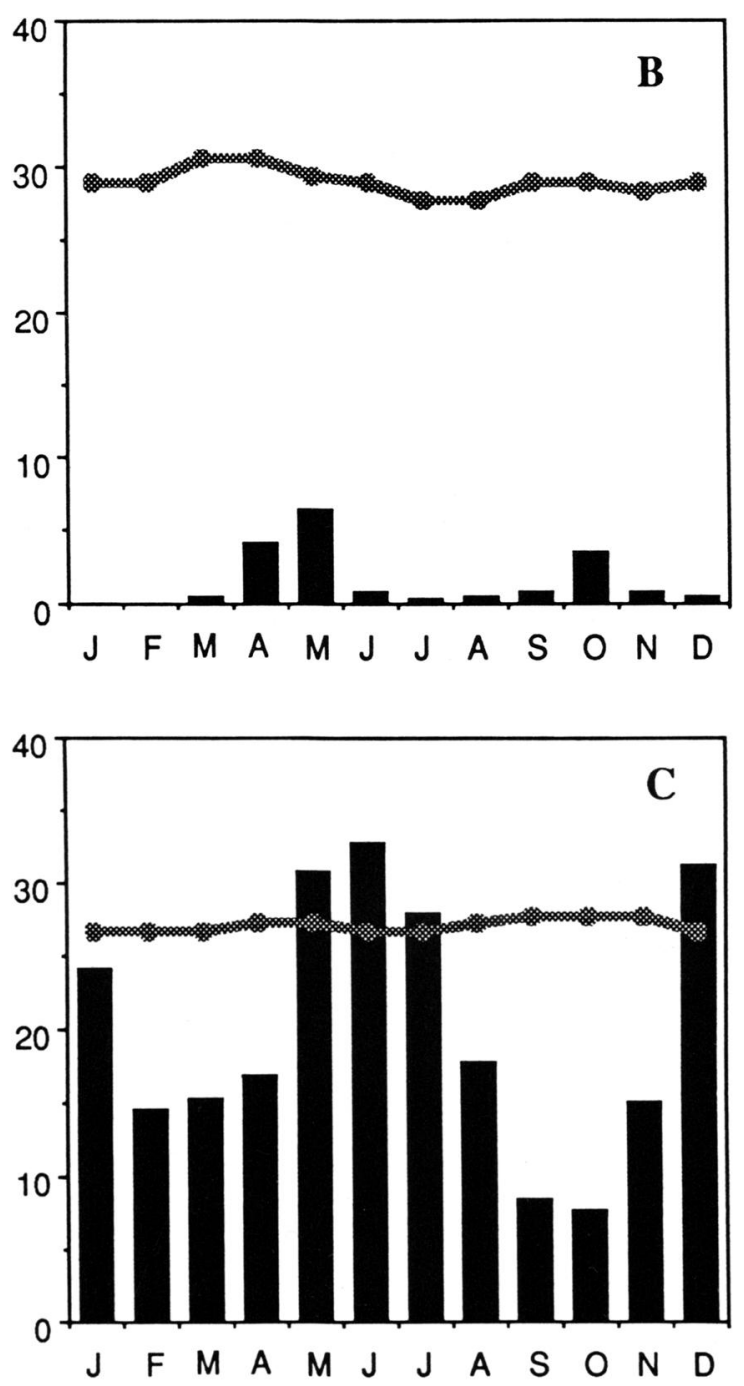

FIGURE 2-Rainfall (solid bars) and temperature (shaded lines) in: A. Mangalore, India; B. Belen Uen, Somalia; and C. Georgetown, Guyana perature fluctuation (e.g., Mangalore, India, Fig. 2A; Rumney, 1968). The rain may fall principally in the coastal regions or farther inland, depending on the topography of the continent.

The strongest monsoonal circulation at present is over Asia, where the summer monsoon low-pressure cell is particularly intense. Several factors contribute to the strength of the summer monsoon: 1) the size of the continent, which contributes to maximum summer heating; 2) the crossequatorial pressure contrast between the low-pressure cell over southern Asia and the subtropical high-pressure cell in the southern Indian Ocean; 3) the Indian Ocean, which is a source of heat and moisture; 4) the effect of the Tibetan Plateau as a high-altitude heat source and conduit for latent heat release; and 5) the thermal isolation of the summer low-pressure center for cool air in northern Asia.

\section{Sensible and Latent Heating and Cross-equatorial Flow}

Initiation of the summer monsoonal circulation occurs when Asia begins to warm up in the Spring (Ramage, 1966). With the warming, the surface air rises and return flow into the southern Indian Ocean subtropical high-pressure cell commences. During the summer monsoon, circulation in the southern Indian Ocean is strongly affected by the circulation in the Northern Hemisphere (Ramage, 1971; Webster et al., 1977). The subtropical high-pressure cell in the southern Indian Ocean has an annual cycle unlike any other. Typically, a subtropical high-pressure cell is centered over the eastern half of the ocean basin it occupies, and its intensity is greatest during the summer, the season of maximal thermal contrast with the adjacent continents. The southern Indian Ocean high-pressure cell, however, occupies the expected position only during January-March. During the height of the Asian summer monsoon, the cell shifts to the west; it is also at its strongest, despite the season (southern winter; see, for example, Knox, 1987, fig. 13.1). Clearly, the intensity and position of the southern Indian Ocean subtropical high-pressure cell, at least during the northern summer, are controlled in large part by the climate to the north (Webster et al., 1977). This illustrates the importance of cross-equatorial pressure contrast in disrupting zonal circulation.

In the Pangaean monsoon, differential heating between Tethys and the summer hemisphere would have been similar to that occurring between the Indian Ocean and Asia during the summer Asian monsoon. However, in Pangaea, the interhemispheric thermal contrast would have been augmented by the even stronger cooling of the largely ter-

$\leftarrow$

(Rumney, 1968). A shows the annual rainfall pattern typical of the Asian monsoon system. $\mathbf{B}$ and $\mathbf{C}$ show the difference between equatorial eastern Africa, which is affected by the Asian monsoon, and equatorial eastern South America, which experiences zonal circulation and normal seasonality. Belen Uen lies at about $5^{\circ} \mathrm{N}$ and Georgetown at about $7^{\circ} \mathrm{N}$. Note the scale change for rainfall. 
restrial Southern Hemisphere. Even without input of heat and moisture from Tethys to the summer hemisphere the thermal contrast between the large land masses flanking the equator would have been strong enough to drive monsoonal circulation; indeed, monsoonal circulation occurs today on Mars, where latent heat processes are minimal or non-existent (Haberle,1986; Young, 1987). Because of the latitudinal distribution of the Pangaean land mass, the seasonally alternating circulation over the large land areas would have occurred in both hemispheres. The high-pressure cell in the winter hemisphere would have "faced" a low-pressure cell in the summer hemisphere across Tethys, and this maximal temperature and pressure contrast would have been semiannual.

A consequence of cross-equatorial flow in the modern Asian monsoon system is that eastern Africa (e.g., Fig. 2B) is much drier than similarly situated regions (equatorial South America, eastern East Indies; e.g., Fig. 2C). In these other regions, the easterlies associated with the ascending Hadley circulation carry warm, very moist air over the land, and the moisture is released as abundant rainfall. Because the equatorial easterlies are diverted by the monsoon, eastern equatorial Africa does not receive much rainfall. Indeed, the greatest rainfall in equatorial Africa is in the west, and this also is attributable to the summer monsoon over Asia. Flow in the vicinity of western equatorial Africa is west to east, the reverse of "normal" equatorial circulation, especially during the northern hemisphere summer. The thermal low over the Sahara might be regarded as an extension of the Asian low, and it is intense enough to reverse equatorial flow (Das, 1986).

Although the monsoonal circulation is initiated by sensible heating, moist processes are very important to the strength of the Asian summer monsoon. In a dry system, the maintenance of convection depends entirely on continued heating at the ground surface. In a moist system, the convection is partly self-propagating, through latent heat release, so long as the moisture supply is continuous. The source of moisture for the Asian monsoon is the Indian Ocean. Air flowing into the monsoon at the surface originates over the southern Indian Ocean and picks up additional moisture as it continues northward over the ocean and becomes warmer. The expanse of warm, equatorial ocean adjacent to Pangaea (Tethys) was comparable to that traversed by the modern air masses flowing from the southern Indian Ocean into the Asian summer monsoon, so the latent energy in the two systems might be expected to have been comparable.

\section{Topographic Effects}

The Tibetan Plateau enhances the summer monsoonal circulation by functioning as a high-altitude heat source. Simply put, the ground surface of the plateau increases the altitude of warm isotherms, so that the temperature at $6000 \mathrm{~m}$ on the plateau is much warmer than the temperature of air at the same altitude over the lowlands. The effect is the same as a rising column of warm air-the relative pressure is low. Today in southwestern India, the
Western Ghats have a similar, though less intense effect on the monsoonal circulation (Ramage, 1966).

Although the consensus is that the cross-equatorial thermal contrast is the primary cause of the monsoon (Young, 1987; Webster, 1987; Murakami, 1987), the importance of the Tibetan Plateau to the strength of the monsoon is well-established (Flohn, 1968; Hahn and Manabe,1975; Das, 1986; Murakami, 1987). Thus, the possible consequences of Pangaean topography must be considered. A particularly pertinent study in this regard is that of Hahn and Manabe (1975), who modeled the Asian monsoonal system with mountains (M) and with no mountains (NM). The major differences in the results of the simulations were the following: 1) The center of the low-pressure cell over Asia was farther to the northeast over northeastern China in the NM case. Even though the low pressure was as intense as the observed and $M$ simulation lows, the effect of this displacement was to decrease the pressure gradient over southern Asia. 2) Latent heat release and, therefore, rainfall did not penetrate as far into the continental interior in the NM simulation as in the M simulation and in the observed monsoonal system. This was partly due to a lower pressure gradient. Summer and winter rainfall was thus predicted to have been confined to the coastal regions, and desert-like conditions were predicted for the interior, as occur in Australia today (Webster, 1981). The distribution of latent and sensible heating in Asia was similar for the two models except in the vicinity of the Tibetan Plateau; the overall effect was that Asia was dominated by sensible heating in the NM simulation and by latent heating in the $M$ simulation, but it should be noted that the climate patterns (e.g., precipitation) actually were quite similar everywhere but over the plateau itself (Hahn and Manabe, 1975, fig. 4.5). 3) The Somali jet, a concentration of northward moving streamlines parallel to the Somalian coast, was predicted by the $M$ simulation but not by the NM simulation. A possible effect is that precipitation in the adjacent region of Africa would be higher in the absence of mountains, whereas in the present system, precipitation in eastern equatorial Africa is low and limited to spring and autumn (Fig. 2B). However, the differences between the $\mathrm{M}$ and NM simulations in precipitation and the position of the inter-tropical convergence zone (ITCZ) in that region were small.

Pangaea was not devoid of mountains. A mountain chain that probably resembled the Andes lay along the northern margin of Tethys, formed during northward movement and subduction of the paleo-Tethyan plate (the present Tien Shan and Nan Shan mountain ranges; Scotese et al., 1979; Klimetz, 1983). These mountains might have enhanced the release of latent heat much as the Western Ghats in southwestern India do now (Ramage, 1966). Pangaea also had an interior plateau that might have been comparable to the Tibetan Plateau. Hay et al. (1982) estimated that the elevation of the proto-Atlantic rift system was as great as $4500 \mathrm{~m}$, not as high as the Tibetan Plateau, but substantially higher than the Colorado Plateau, which does have a similar but weaker, effect on circulation. In particularly, both plateaus, as high-altitude heat sources 


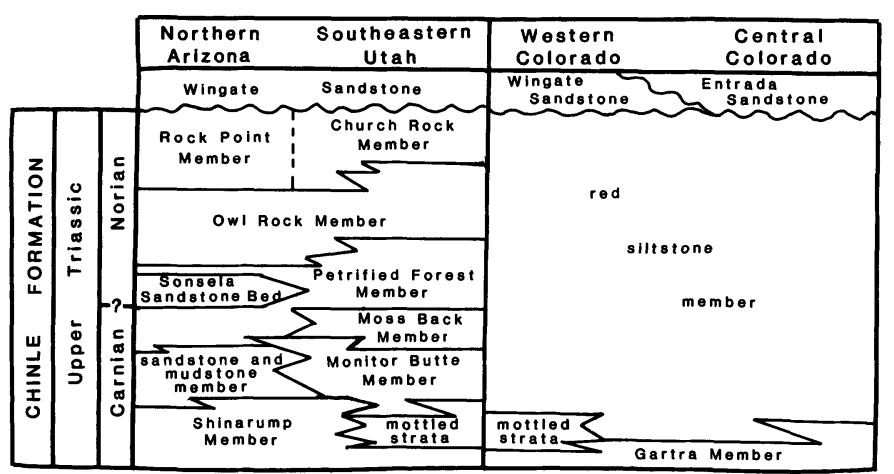

FIGURE 3-Stratigraphic relations of the Chinle Formation and adjacent strata in the study area.

and conduits for latent heat release, enhance precipitation in the continental interior. If the rift system was lower, rainfall would have been restricted to the coastal regions, as in the Hahn and Manabe (1975) NM simulation (see also Kutzbach and Gallimore, 1989). Parrish (1988) termed this a "modified" monsoon to signify that the interhemispheric thermal contrast and cross-equatorial flow that are characteristic of a strong monsoon were present, but that the intense seasonal rainfall was limited to the coastal regions.

The so-called heat low (referring to sensible heat) centered over northwestern India and Pakistan, which remain arid through the summer monsoon, is maintained and intensified by high-level subsidence of air that is warmed by the release of latent heat over southwestern and northeastern India (Ramage, 1966; Das, 1986). This heat low blocks the northward penetration of moist air in that region (Krishnamurti and Ramanathan, 1982). If part of the return flow from latent heat release over the Tethyanmargin mountains was in the upper atmosphere over the interior, as occurs over Pakistan and northwestern India today, the interior would be expected to have been arid (Parrish et al., 1982). Major support for the monsoon hypothesis is the evidence of widespread aridity in Pangaea, which prompted Robinson (1973) to suggest monsoonal circulation in the first place.

\section{Climatic Consequences of the Pangaean Monsoon}

Four effects of Pangaean monsoonal circulation are predicted: 1) Evidence of seasonality, especially of moisture, will commonly be strong, and rocks containing such evidence will be widespread. 2) The equatorial region, particularly in the east, would have been dry relative to the high-latitude regions of Pangaea or to the equatorial region at other times in Earth history. At its greatest intensity, the monsoon might have been strong enough to reverse equatorial flow, and in that event the western equatorial region of Pangaea will be relatively humid. 3) Climatic belts would not have been zonal, that is, parallel to latitude. 4) The conditions described above should have reached a maximum in the Triassic. This is because the hypothesis of Pangaean monsoonal circulation is dependent on the size of Pangaea and the cross-equatorial contrast between northern and southern halves, and that contrast would be expected to be maximal when the contrasting continental areas are about equal in size and at about the same latitude. Thus, the period of strongest monsoonal circulation is expected to have been in the Triassic, when these conditions were met (Fig. 1; Parish, 1985; Parrish et al., 1986). Whether the maximum occurred earlier or later in the Triassic Period depends on the apparent polar-wander path for Pangaea, which for the later part of the Triassic is controversial (see Discussion).

Substantial support for all of these predictions has been documented from many parts of the world (e.g., Olsen, 1986; Parrish and Peterson, 1988), but a comprehensive review of this literature is beyond the scope of this paper. Rather, we concentrate on the evidence contained in the Chinle Formation, whose deposition near the west coast of Pangaea is particularly relevant to the predictions of seasonality, as well as to reversal of equatorial flow in the atmosphere during the Triassic monsoon maximum, as discussed briefly by Parrish and Peterson (1988).

\section{THE CHINLE FORMATION}

\section{Regional Setting}

Through most of its extent on the Colorado Plateau, the Chinle Formation unconformably overlies the Lower and Middle(?) Triassic Moenkopi Formation or equivalent rocks. Locally in the Defiance uplift of northeastern Arizona and in western Colorado, the Chinle overlies Permian strata or older rocks. The Chinle is as much as $500 \mathrm{~m}$ thick and is unconformably overlain by the Lower Jurassic Wingate Sandstone or Moenave Formation and, locally to the east in central Colorado and northwestern New Mexico, by the Middle Jurassic Entrada Sandstone.

Chinle Formation stratigraphy is complex, and the reader is referred to Stewart et al. (1972) for a comprehensive review of the history of nomenclature of Upper Triassic rocks on the Colorado Plateau. To facilitate subsequent sedimentological and paleontologic descriptions, Chinle stratigraphy in the study area is summarized in Figure 3. In general, mottled strata and the Shinarump or Gartra Members lie near or at the base of the Chinle; these are succeeded in turn by the informal sandstone and mudstone member and Monitor Butte Member, Moss Back Member, Petrified Forest Member, Owl Rock Member, and Church Rock or Rock Point Members. In western and central Colorado, strata above the Gartra Member and mottled member are assigned to the informal red siltstone member (Stewart et al., 1972; Dubiel 1989a; Dubiel and Skipp, 1989).

The Upper Triassic Chinle Formation on the Colorado Plateau was deposited in a continental back-arc basin located about $5-15^{\circ}$ north of the paleoequator near the west coast of Pangaea (Fig. 1; e.g., Van der Voo et al., 1976; Dickinson, 1981; Pindell and Dewey, 1982; Ziegler et al.,1983; Parrish and Peterson, 1988; Bazard and Butler, 
in press). A magmatic-volcanic arc on part of the western edge of the Triassic continent probably provided volcanic ash and clastic sediment to the Chinle depositional basin (Stewart et al., 1972; Blakey and Gubitosa, 1983; BusbeySpera, 1988), although a clearly defined source area has not been identified (Stewart et al., 1986). The Chinle depositional basin was centered about the Four Corners region of Colorado, Utah, Arizona, and New Mexico (Fig. 4; Blakey and Gubitosa, 1983; Dubiel, 1987a, 1989a, b). Clastic sediment was supplied to the Chinle basin north- and northwestward from the Mogollon highlands, which lay in southern Arizona and northern Mexico, and south-, west-, and northwestward from the ancestral Uncompahgre highlands in southwestern Colorado and the ancestral Front Range highlands in central Colorado (Stewart et al., 1972; Blakey and Gubitosa, 1983; Dubiel, 1987a, 1989a, b).

\section{Sedimentological Evidence for Chinle Paleoclimate}

Sedimentological studies of the Chinle Formation on the Colorado Plateau have provided a variety of evidence that bears on the interpretation of paleoclimate during the Late Triassic. In contrast to the predominance of eolian deposition on the Colorado Plateau in the Permian and Jurassic Periods (e.g., Peterson, 1988), Late Triassic deposition was characterized by a fluvial-deltaic-lacustrine system replete with extensive marshes, bogs, rivers, floodplains, and lakes (e.g., Stewart et al., 1972; Blakey and Gubitosa, 1983; Dubiel, 1983, 1987a, 1989b). Blakey and Gubitosa $(1983,1984)$ described perennial fluvio-lacustrine complexes throughout most of Chinle deposition followed by increasingly arid conditions in the upper part of the Chinle. Sedimentological studies of the Chinle in southeastern Utah documented a complex fluvial-lacustrine system and also interpreted Chinle climate as tropical monsoonal, that is, with significant precipitation but punctuated by seasonally dry periods, with an increase in aridity in the upper part of the Chinle (Dubial, 1983, 1984, 1986, 1987a, b, c, 1989a). Similar interpretations of wet conditions punctuated by dry periods were proposed for the Chinle in Petrified Forest National Park, Arizona (Bown et al., 1983) and for the correlative Upper Triassic Dolores Formation in southwestern Colorado (Blodgett, 1988). Aquatic habitats indicated by faunal, paleobotanical, and sedimentological evidence point to abundant and perennial water in the depositional system in the Four Corners area. Additionally, trace fossils and floodplain paleosols indicate that sedimentary facies and ground water tables fluctuated in response to episodic flooding that probably resulted from periodic, and perhaps seasonal, input of moisture.

The Chinle Formation includes complexly interfingered continental lithofacies (Blakey and Gubitosa, 1983; Dubiel, 1983, 1984, 1987a, b, 1989a; Dubiel and Skipp, 1989), many of which have paleoclimatic and paleoecologic implications (Dubiel, 1987c; Good et al., 1987). For this discussion, Chinle lithofacies assemblages and their attendant depositional environments are broadly grouped as 1) distal, basinal or lowland settings representative of the

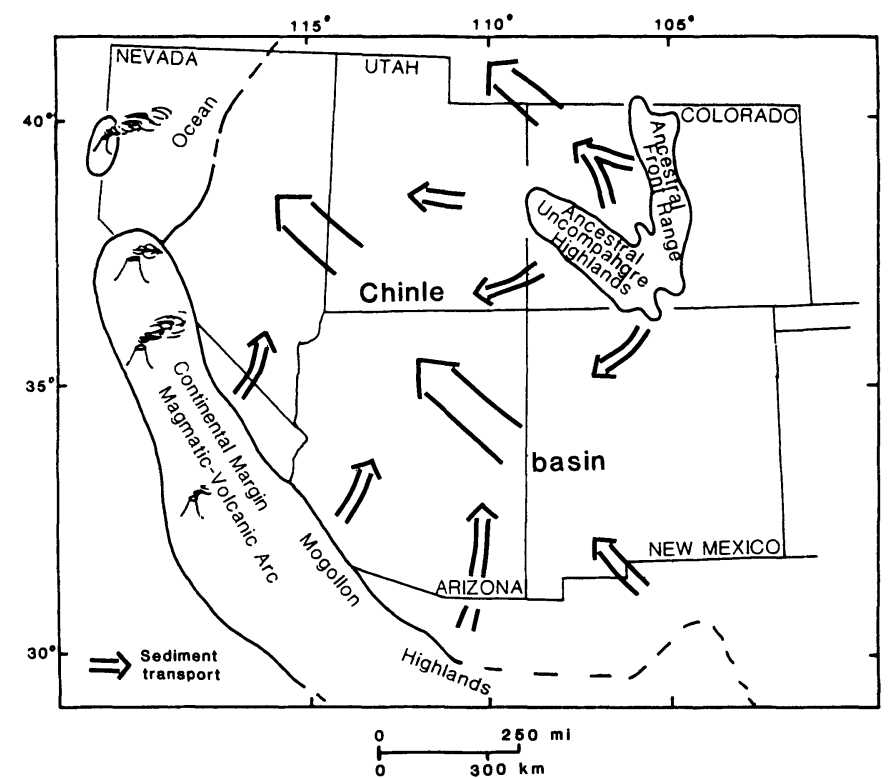

FIGURE 4-Paleogeographic reconstruction of the Chinle depositional basin in the southwestern United States showing general direction of sediment transport from the bounding highlands. Modified from Dickinson (1981), Blakey and Gubitosa (1983), and Dubiel (1989b).

Four Corners area and 2) proximal or upland settings characteristic of northwestern Colorado (see also, Blakey and Gubitosa, 1983). It is noted, however, that depositional facies of both the Chinle (Dubiel et al., 1989b) and the correlative Dolores Formation (Blodgett, 1988) exposed on the southwestern flank of the Uncompahgre Plateau in southwestern Colorado are similar to the proximal facies in northwestern Colorado. This similarity is the result of proximity to the source area of the Chinle and Dolores, despite being deposited to the southwest and west into the Chinle basin of the Four Corners area.

\section{Depositional Setting-Four Corners Region}

In the Four Corners region, the Chinle Formation is composed of, in ascending order, the Shinarump, Monitor Butte, Moss Back, Petrified Forest, Owl Rock, Church Rock, and Rock Point Members (Fig. 3; Stewart et al., 1972). Contacts between members commonly are gradational or interfingered, reflecting the complex nature of the continental depositional system. The Chinle was deposited in paleovalleys eroded in the underlying Moenkopi Formation and locally in older rocks. Lithofacies and depositional environments are summarized in Table 1.

The Shinarump Member is characterized by white to yellow and gray, medium- to coarse-grained and conglomeratic sandstone that displays complex cut-and-fill structures, lenticular internal scour surfaces, and rare large-scale lateral-accretion bedding. Large-scale, trough cross-stratification and less abundant tabular-planar crossstratification and horizontal laminations are common sedimentary structures. Sandstone bodies grade laterally into 
TABLE 1-Lithofacies and depositional environments of the Chinle Formation, Four Corners region.

\begin{tabular}{|c|c|c|}
\hline $\begin{array}{l}\text { Stratigraphic } \\
\text { unit }\end{array}$ & Lithofacies & Depositional environment \\
\hline $\begin{array}{l}\text { Church Rock } \\
\text { Member }\end{array}$ & $\begin{array}{l}\text { Orange to red and brown sand- } \\
\text { stone, siltstone and mudstone, } \\
\text { with minor limestone; locally } \\
\text { has large-scale lateral accretion } \\
\text { bedding }\end{array}$ & $\begin{array}{l}\text { Lacustrine and fluvial } \\
\text { mudflats; minor high- } \\
\text { sinuosity fluvial sys- } \\
\text { tems; eolian sand sheets }\end{array}$ \\
\hline $\begin{array}{l}\text { Owl Rock } \\
\text { Member }\end{array}$ & $\begin{array}{l}\text { Pink to gray and green limestone; } \\
\text { red and orange sandstone, silt- } \\
\text { stone, and mudstone }\end{array}$ & $\begin{array}{l}\text { Lacustrine basin and la- } \\
\text { custrine mudflats }\end{array}$ \\
\hline $\begin{array}{l}\text { Petrified For- } \\
\text { est Mem- } \\
\text { ber }\end{array}$ & $\begin{array}{l}\text { Lavender to red and brown sand- } \\
\text { stones and variegated mud- } \\
\text { stones; large-scale crossbedding } \\
\text { and lateral accretion bedding; } \\
\text { local carbonate nodules and } \\
\text { black, organic-rich mudstones }\end{array}$ & $\begin{array}{l}\text { Fluvial channels and } \\
\text { point bars; paleosols } \\
\text { and minor lacustrine } \\
\text { marshes }\end{array}$ \\
\hline $\begin{array}{c}\text { Moss Back } \\
\text { Member }\end{array}$ & $\begin{array}{l}\text { Brown to gray sandstone and } \\
\text { nodule-bearing conglomerate; } \\
\text { minor red mudstone with car- } \\
\text { bonate nodules }\end{array}$ & $\begin{array}{l}\text { Low-sinuosity fluvial } \\
\text { channels; floodplains } \\
\text { with calcic and vertic } \\
\text { paleosols }\end{array}$ \\
\hline $\begin{array}{l}\text { Monitor } \\
\text { Butte } \\
\text { Member }\end{array}$ & $\begin{array}{l}\text { Gray to green sandstone, silt- } \\
\text { stone, and mudstone; tan lime- } \\
\text { stone; black, organic-rich mud- } \\
\text { stone }\end{array}$ & $\begin{array}{l}\text { Fluvial and crevasse-splay } \\
\text { channels; lacustrine del- } \\
\text { tas and marshes }\end{array}$ \\
\hline $\begin{array}{l}\text { Shinarump } \\
\text { Member }\end{array}$ & $\begin{array}{l}\text { Yellow to gray sandstone and } \\
\text { conglomerate with minor gray } \\
\text { mudstone; large-scale crossbed- } \\
\text { ding; fills scours and paleoval- } \\
\text { leys }\end{array}$ & $\begin{array}{l}\text { Fluvial channels and val- } \\
\text { ley fills }\end{array}$ \\
\hline
\end{tabular}

siltstone and mudstone that contains carbonized, whole and fragmented plant fossils.

The Shinarump Member represents fluvial strata deposited under conditions of rising base level in the lowest parts of the paleovalleys cut into the Moenkopi Formation (Fig. 5; Dubiel, 1983, 1987a, b, c). The transition from massive, conglomeratic, and tabular-planar stratified sandstone at the base upward into medium-grained, trough cross-stratified sandstone represents a change from primarily bedload deposition in braided streams with transverse bars to mixed-load deposition in low-sinuosity fluvial systems dominated by sand waves and local point bars.

A gradational contact exists between the Shinarump Member and the overlying Monitor Butte Member. The Monitor Butte contains purple-mottled, yellow, brown, and red sandstone and siltstone; black, organic-carbon-rich mudstone; green, bentonitic, silty sandstone and mudstone; red, calcareous mudstone; and tan to pink and green limestone. These diverse lithofacies represent a variety of continental depositional environments.

A purple-mottled sandstone unit typically occurs at the base of the Monitor Butte Member. The mottled unit is characterized by large, irregular mottles of dark purple, lavender, yellow, and white that reflect varying concen- trations of iron-bearing minerals. Ubiquitous in the mottled unit are large cylindrical trace fossils interpreted to be the casts of lungfish burrows (Dubiel et al., 1987, 1988, 1989a) and decapod burrows (Hasiotis and Mitchell, 1989). Both the burrows and the mottled coloration reflect fluctuating water tables within the original sediments (Dubiel et al., 1987). The mottling locally extends downward into the Moenkopi at the same level of development in the Chinle and, in both cases, represents a gleyed paleosol formed by fluctuating water tables. The fluctuating water tables produced alternating oxidizing and reducing conditions that resulted in the redistribution of iron and the mottling. Lungfish are believed to have formed their burrows for aestivation in response to seasonal dryness, whereas the crayfish burrowed to keep their living chambers at the bottom of the burrows beneath the water table.

The purple-mottled units can be traced laterally into gray and purple siltstones that contain finely comminuted fragments of plant material. The siltstones can be traced farther laterally and distally into gray to black, very thinly laminated, organic-carbon-rich mudstones and shales. The black mudstones typically contain abundant conchostracans, fish scales, and fragmented fish bones, whereas gray mudstones that have a lower organic-carbon content con- 
tain abundant, calcareous Darwinula sp. ostracodes and plant fragments (Dubiel, 1983). The black mudstones are as thick as $15 \mathrm{~m}$ and in places contain coal beds as thick as $20 \mathrm{~cm}$. Locally, the mudstones are interbedded with tan, thin-bedded limestones that contain Darwinula sp. ostracodes, thin-shelled unionid bivalves, and small vertebrate bones (Dubiel, 1987a, b; Parrish and Good, 1987).

These Monitor Butte Member strata were deposited by fluvial systems and in lacustrine-marsh and bog-wetland environments (Dubiel, 1984, 1987a, b, c). The conchostracans and Darwinula sp. ostracodes, along with the relatively high organic content of the black mudstones and shales and thin carbonates, suggests these strata were deposited in lakes and marshes (Dubiel, 1983, 1987a, b, c). The freshwater salinity is supported by organic-carbon contents as high as 20 weight percent in the mudstones and the occurrence of coal beds, which require peat production in bogs and marshes with a continually high, fresh water table (McCabe, 1986).

Overlying the marsh and lacustrine units are thin-bedded, laterally extensive, burrowed limestones and Darwinula sp. ostracode-bearing mudstones as much as $5 \mathrm{~m}$ thick. These, in turn, are overlain by green, bentonitic, sandstones and mudstones that commonly exhibit large-scale foreset bedding as much as $25 \mathrm{~m}$ thick (Dubiel, 1983). The green beds contain finely comminuted black, plant fragments and whole specimens of several Late Triassic plants, including true ferns (Ash et al., 1982) and the casts of giant horsetails (Equisetites sp.) (Holt, 1947; Ash, 1967, 1972; Dubiel, $1987 \mathrm{a}, \mathrm{b})$ that are as much as $20 \mathrm{~cm}$ in diameter.

These Monitor Butte beds have been interpreted as an extensive system of fluvial and deltaic distributary channels and splays, and lacustrine, prodelta, and delta deposits (Dubiel, 1983, 1987a, b). The fluvial and deltaic systems prograded northwest into large perennial lakes, filling in most of the remnant topography of the original Moenkopi paleovalleys. The bentonitic clays and the presence of altered lithic clasts (Schultz, 1963) and relict glass shards (Waters and Granger, 1953) indicate that volcanic ash was a major component of the sediment.

The Moss Back Member locally overlies the Monitor Butte Member (Fig. 3) and crops out in a narrow belt between White Canyon, Utah and Canyonlands National Park, Utah (Stewart et al., 1972; Blakey and Gubitosa, 1983; Dubiel, 1983). The Moss Back consists of brown to gray, medium-grained sandstone and carbonate-nodule conglomerate with minor mudstone lenses. Sedimentary structures include abundant tabular-planar and large-scale trough crossbedding and less abundant horizontal laminations. The sandstone bodies are lenticular and exhibit internal scour surfaces and cut-and-fill structures. The thick tabular planar-and trough-crossbedded sandstones interfinger laterally with red, thin-bedded sandstones, siltstones, and mudstones that contain transported, thickshelled unionid bivalves (Dubiel, 1987a, b; Parrish and Good, 1987), isolated carbonate nodules, and abundant, 1 $\mathrm{cm}$-diameter trace fossils with a distinctive, external ropey texture.

The lithology and structures in Moss Back sandstones

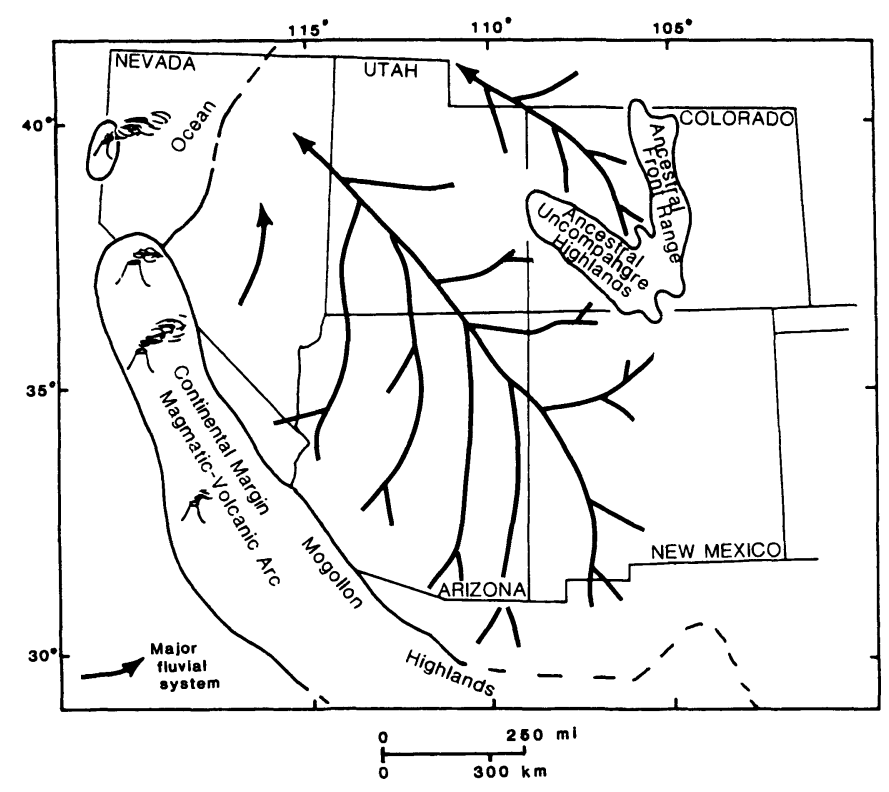

FIGURE 5-Paleographic reconstruction of Shinarump and Gartra Member fluvial systems. Note northwest-trending trunk streams in both the Four Corners region and in northwestern Colorado. Tributary streams flowed off the bounding highlands to the trunk streams.

indicate deposition by fluvial processes. The lenticular, coarse-grained sandstones were deposited as bedload in low-sinuosity fluvial channels. The red, thin-bedded units are levee, crevasse splay, and overbank deposits that contain carbonate-nodule paleosol horizons. These paleosols, calcic vertisols, were the source of the carbonate nodule clasts within Moss Back conglomerates. The thick-shelled unionids were washed out of perennial fluvial systems and onto crevasse splays during flood events (Parrish and Good, 1987). The trace fossils resemble Scoyenia gracilis, which is generally attributed to a sediment-ingesting arthropod and is commonly associated with shallow aquatic settings subject to periodic drying (e.g., Ekdale et al., 1984).

An increase in the rate of clastic sedimentation, associated with an increase in volcanic activity and ash production, resulted in the progradation of the Monitor Butte and the overlying Moss Back fluvial, crevasse splay, and deltaic systems (Blakey and Gubitosa, 1983; Dubiel, 1983, 1987a, 1989b). The Monitor Butte and Moss Back Members were deposited as a westward- to northwestwardtrending system of fluvial and lacustrine-deltaic distributary channels, subaerial and subaqueous crevasse splays, and lacustrine, lacustrine-marsh, and lacustrine-delta deposits (Fig. 6; Dubiel, 1987a, b, 1989b). Green Monitor Butte rocks represent subaqueous lacustrine, marginallaustrine, and fresh-water marsh deposition and contain abundant detrital organic matter, carbonized plant fossils, and casts of giant horsetails. As the system prograded to the northwest, Moss Back fluvial channels, splays, and floodplains deposited typically red strata that lack organic matter and plant fossils; organic matter was probably oxidized and destroyed in subaerial settings. 


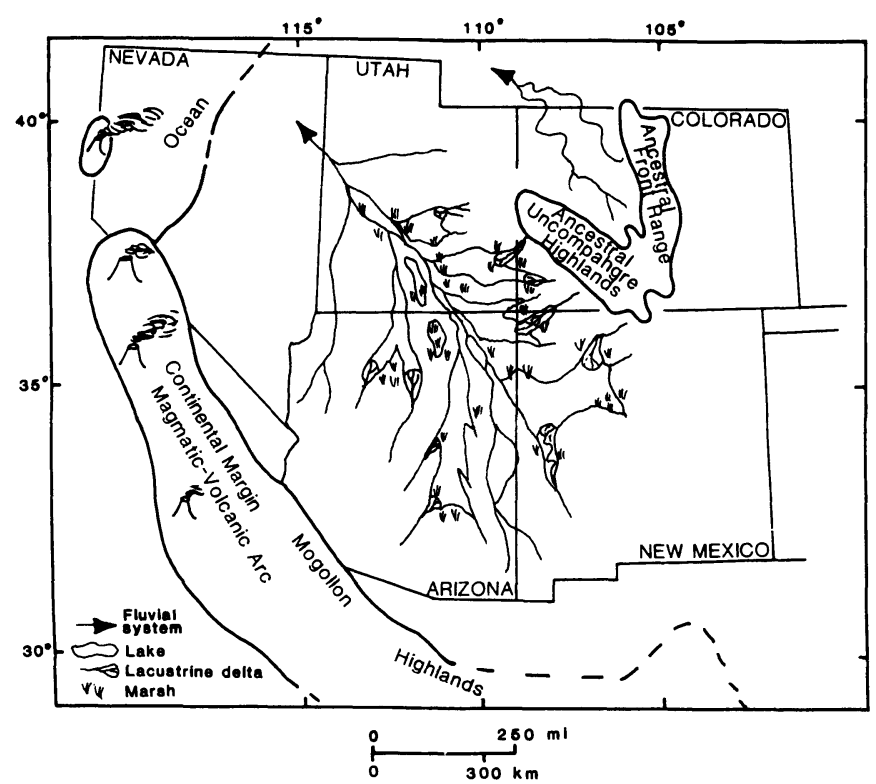

FIGURE 6-Paleogeographic reconstruction of Monitor Butte, Moss Back, and Petrified Forest lacustrine, marsh, and fluvial systems in the Four Corners region and fluvial-floodplain systems in northwestern Colorado.

Overlying the Moss Back Member are lavender and brown sandstones and variegated mudstones of the Petrified Forest Member. The bentonitic sandstones and thin carbonate-nodule conglomerates typically exhibit largescale trough cross-stratification, large-scale internal scour surfaces, and lateral-accretion bedding. Sandstones grade laterally into red-brown mudstones that contain pedogenic carbonate nodules identical to those in Moss Back floodplain paleosols. Interfingered with the sandstones are finer grained bentonitic strata that contain abundant vertebrate remains, lungfish toothplates, gastropods, and thin-shelled unionid bivalves (Dubiel, 1987a; Parrish and Good, 1987). Isolated outcrops of black, organic-carbon-rich and conchostracan-bearing mudstone are present in the Petrified Forest Member.

The Petrified Forest Member represents fluvial sandstones and floodplain mudstones that interfinger with crevasse-splay deposits and isolated marsh mudstones. The abundance of lateral-accretion bedding, numerous splay deposits, and the presence of floodplain mudstones that completely encase the sandstones indicate deposition by high-sinuosity streams that were subject to frequent avulsion events. Fossils of aquatic phytosaurs, lungfish, and lacustrine unionid bivalves (Parrish and Good, 1987) support the interpretation of rivers, lakes, and marshes for the Petrified Forest. Altered glass shards (Waters and Granger, 1953) and bentonitic mudstones (Schultz, 1963) in the Petrified Forest Member indicate that volcanic ash continued to form a significant component of the sediment. Water tables continued to be high during Petrified Forest deposition, as evidenced by the presence of aquatic vertebrates, lacustrine unionids and pulmonate gastropods, and organic-rich marsh deposits. Pedogenic development of carbonate nodules in Moss Back and Petrified Forest clay-rich floodplain vertisols in a tropical setting indicates that precipitation was episodic, and perhaps seasonal (Mohr et al., 1972; Young, 1976).

The Petrified Forest Member interfingers with or grades upward into the pink and green limestones and red to orange siltstones of the Owl Rock Member. Owl Rock limestones range from $10 \mathrm{~cm}$ to $2 \mathrm{~m}$ in thickness, can be traced laterally for several tens of miles, and typically display a mottled coloration and knobby-weathered texture. The mottling and knobby texture represent extensive bioturbation, an interpretation supported by numerous cylindrical trace fossils interpreted to be lungfish and crayfish burrows (Dubiel et al., 1987; Hasiotis and Mitchell, 1989) that are locally abundant in the limestones and that extend down into underlying siltstones. Locally the limestones contain ostracodes, but other body fossils are very rare. At Monument Valley in northeastern Arizona, Owl Rock limestones are laminated on a very fine scale, indicating a lack of bioturbation. The laminae are composed of couplets of clastic, clay-rich zones alternating with micrite-dominated zones. The laminae appear to represent periodic alternations of clastic sedimentation and carbonate precipitation. Interbedded with the limestones are thick-bedded, massive siltstones that exhibit no physical sedimentary structures, but that locally contain abundant trace fossils.

Owl Rock strata were deposited in an extensive lacustrine environment that developed in response to continued subsidence and to a reduction in clastic and volcanic sediment input (Fig. 7). The lack of fluvial-channel deposits, and the abundant bioturbation by lungfish, crayfish, and small invertebrates in both the limestones and the siltstones, indicate that deposition occurred in large lakes and on lake margins. Clastic-carbonate couplets in laminated limestones suggest that alternating carbonate precipitation and clastic sedimentation may have been related to seasonal precipitation and runoff to the lake. The larger scale interbedding of siltstone and limestone in the Owl Rock is suggestive of longer term climatic fluctuations, possibly representing Milankovitch cycles (Dubiel, 1989b, c).

Orange to red and brown sandstones and siltstones of the Church Rock Member overlie the Owl Rock Member. The Church Rock has a limited distribution (Stewart et al., 1972) and is not present at every locality. Sandstones are fine- to medium-grained and are either structureless or contain faint, large-scale trough cross-stratification and minor lateral-accretion bedding. Many of the units contain small, but abundant, meniscate back-filled trace fossils. Locally at the top of the unit, mudstones contain desiccation cracks as much as $10 \mathrm{~cm}$ wide and $1 \mathrm{~m}$ deep that are filled with sandstone of the overlying Wingate Sandstone. Distribution of the mudcracks on the outcrop in three dimensions suggests the associated mudcrack polygons were several meters across.

The Rock Point Member is present in the Defiance uplift in northeastern Arizona. The Rock Point consists of red- 


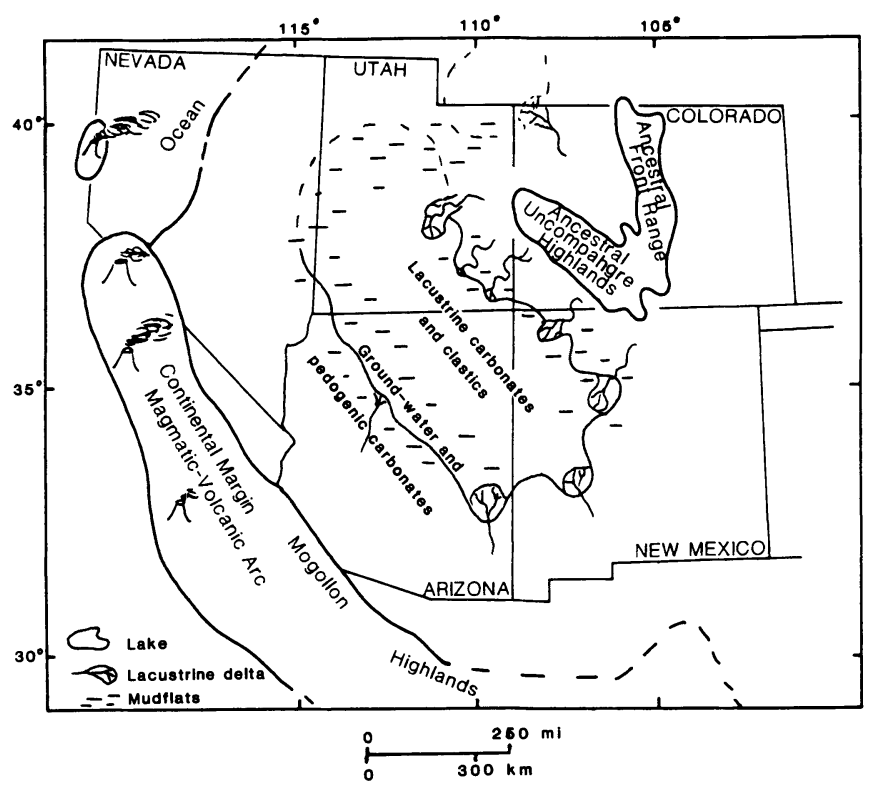

FIGURE 7-Paleogeographic reconstruction of OwI Rock Member lacustrine and marginal lacustrine systems. Lacustrine strata occupied the central portion of the northwest-trending basin. The Owl Rock lake expanded and contracted in response to climatic variations.

dish-brown, very fine grained sandstone and minor siltstone and silty sandstone virtually identical to the laterally equivalent Church Rock Member (Stewart et al., 1972; Dubiel, 1989a). Rock Point sandstones weather as thinto-thick-bedded ledges, whereas finer grained units weather to steep slopes. Locally, sandstones in the upper part of the Rock Point exhibit large-scale crossbeds with upward-coarsening laminae, one of the few criteria diagnostic of eolian deposition. Finer grained units contain thin, horizontal laminations and very small trace fossils. Large mudcracks are locally abundant at the top of the Rock Point. The Church Rock and Rock Point Members are unconformably overlain by the Lower Jurassic Wingate Sandstone.

Sandstones and mudstones of the Church Rock and Rock Point Members were deposited on lacustrine or playa mudflats traversed by small fluvial systems (Fig. 8) (Dubiel, 1987a, 1989a, b). The large-scale, eolian cross-stratification and the large mudcracks indicate that drier periods and desiccation were more prominent during deposition of the uppermost part of the Chinle. Moreover, the singular aspect and large size of both the mudcracks and the mudcrack polygons indicate that the sediments were water saturated before drying out, and that the drying probably occurred as a single event. Preliminary examination of petrographic thin sections of the upper part of the Chinle indicate that the red color of these rocks, in contrast to the variegated colors of the lower Chinle, is due to a greater development of diagenetic hematite. The greater development of hematite in this part of the Chinle may be related to the lack of organic carbon in the rocks. Both hematite development and the decreased organic carbon

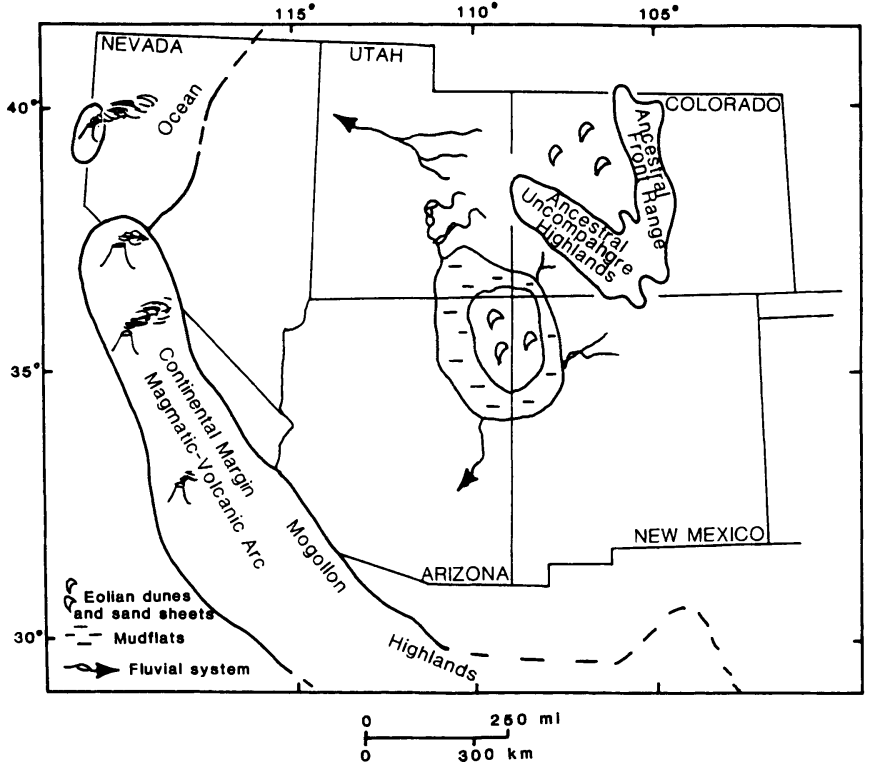

FIGURE 8-Paleogeographic reconstruction of Church Rock and Rock Point Member marginal lacustrine mudflats and eolian sand sheets.

are thought to reflect deposition in the more oxygenated lacustrine mudflat and playa environments. The red color by itself is not de facto evidence of arid climates, but merely reflects the increased hematite content.

Sedimentologic evidence suggests that lower water table conditions developed during the final stages of Chinle deposition. Lacustrine mudflat siltstones and mudstones, ephemeral fluvial-channel sandstones, and eolian sandsheet and dune deposits of the Church Rock and Rock Point Members were deposited under extended dry periods, although intermittent flood events are indicated by interfingered fluvial strata, trace fossils, and small-scale sedimentary structures such as ripple marks and adhesion ripples. The inception of extensive lacustrine clastic-mudflat deposition rather than carbonate precipitation, and the presence of desiccation cracks within these deposits, indicate that the environment was episodically wet. The predominance of eolian sand-sheet and dune deposits in the upper part of the Rock Point Member (Dubiel, 1989a) points to significant climatic drying at the close of the Late Triassic, a scenario suggested by several authors (e.g., McKee, 1959; Blakey and Gubitosa, 1983, 1984; Dubiel, 1987a, b, 1989a). The overlying eolian erg deposits of the Wingate Sandstone attest to the transition to predominantly eolian sedimentation and more arid climatic conditions in the Early Jurassic.

\section{Depositional Setting-Northwestern Colorado}

The Chinle Formation in northwestern Colorado provides additional sedimentologic evidence for Late Triassic monsoonal climates. The Chinle in this area was derived primarily from clastic sediment shed off of the ancestral Uncompahgre and ancestral Front Range uplifts (Fig. 4). 
TABLE 2-Lithofacies and depositional environments in the Chinle Formation, northwestern Colorado.

\begin{tabular}{|c|c|c|}
\hline $\begin{array}{l}\text { Stratigraphic } \\
\text { unit }\end{array}$ & Lithofacies & Depositional environment \\
\hline $\begin{array}{l}\text { Red Siltstone } \\
\text { Member } \\
\text { (upper part) }\end{array}$ & $\begin{array}{l}\text { Reddish-orange sandstone; hori- } \\
\text { zontally bedded, wavy lamina- } \\
\text { tions, and thin mudstone } \\
\text { drapes }\end{array}$ & Eolian sand sheets \\
\hline $\begin{array}{l}\text { Red Siltstone } \\
\text { Member } \\
\text { (middle } \\
\text { part) }\end{array}$ & $\begin{array}{l}\text { Reddish-brown sandstone, silt- } \\
\text { stone, and mudstone; lateral } \\
\text { accretion bedding; carbonate } \\
\text { nodules; rhizoliths and biotur- } \\
\text { bation }\end{array}$ & $\begin{array}{l}\text { Fluvial channels, point } \\
\text { bars; floodplain paleo- } \\
\text { sols; minor lacustrine } \\
\text { deposits }\end{array}$ \\
\hline $\begin{array}{l}\text { Gartra Mem- } \\
\text { ber (lower } \\
\text { part) }\end{array}$ & $\begin{array}{l}\text { Reddish-brown sandstone and } \\
\text { conglomerate; lenticular; } \\
\text { crossbedded }\end{array}$ & $\begin{array}{l}\text { Fluvial channels and val- } \\
\text { ley fills }\end{array}$ \\
\hline
\end{tabular}

About $300 \mathrm{~m}$ of reddish-brown to reddish-orange mudstone, siltstone, fine-grained sandstone, and lesser amounts of dark-gray to reddish-purple conglomerate and sandstone were deposited in fluvial, floodplain, and lacustrine environments in a setting proximal to the orogenic uplifts (Table 2). The Gartra Member at the base of the Chinle is overlain by mottled strata and by the informal red siltstone member (Fig. 2; Stewart et al., 1972; Dubiel and Skipp, 1989). Correlative rocks of the Upper Triassic Dolores Formation deposited in southwestern Colorado are sedimentologically similar to the Chinle Formation in western Colorado and represent proximal facies derived from the southwest flank of the ancestral Uncompahgre uplift (see also, Blodgett, 1988).

The Gartra Member consists of coarse-grained sandstone and conglomerate that fills small paleovalleys cut into underlying rocks. Sandstones and conglomerates are thin to thick bedded and contain planar and trough crossbeds, large lenticular scours, and minor climbing-ripple stratification. Both the size of sedimentary structures and the grain size of the sandstones decrease upward in the unit. The fluvial-channel deposits of the Gartra at the base of the Chinle are coarser grained than those higher in the section, are multi-storied, and lack lateral accretion stratification. The basal fluvial units of the Gartra represent deposition in braided to low-sinuosity fluvial systems. Overlying the Gartra, the mottled member contains purple mottles similar to those in the mottled unit of the Monitor Butte Member in the Four Corners area. The mottled strata grade upward into the overlying red siltstone member, which consists of reddish-brown mudstones, siltstones, and sandstones.

The reddish-brown mudstones, siltstones, and sandstones of the upper part of the Chinle Formation in this region were deposited in a succession of fluvial-channel, point-bar, crevasse-splay, floodplain, lacustrine, and eolian sand-sheet environments (Dubiel et al., 1989b; Dubiel and Skipp, 1989; Dubiel, in press). The abundance of largescale, lateral accretion stratification and laterally extensive fine-grained strata indicates that at least some Chinle fluvial systems were high-sinuosity streams with mixed- to suspended-sediment loads; the laterally extensive floodplains contain local lacustrine strata.

Chinle floodplain deposits in northwestern Colorado are characterized by paleosols containing petrocalcic horizons, interpenetrating sand-filled mudcracks, pseudoanticlines indicative of paleovertisol development, abundant carbonate-cemented rhizoliths, and minor mollusc-bearing crevasse-splay and lacustrine deposits. The uppermost part of the Chinle in this region is characterized by eolian sandsheet strata (Dubiel, 1988; Dubiel et al., 1989b; Dubiel and Skipp, 1989; Dubiel, in press).

The fluvial, floodplain, and lacustrine depositional facies indicate that water was abundant in this basin of the depositional system, at least until the final stages of eolian sand-sheet deposition. The fine-grained nature of the fluvial and point-bar strata and the abundant lateral-accretion deposits indicate high-sinuosity fluvial systems with abundant suspended-sediment load. However, the accumulation of calcic and vertic horizons in clay-rich finegrained floodplain paleosols and abundant desiccation cracks in proximal floodplain deposits in a tropical setting reflect a seasonal input of moisture (e.g., Mohr et al., 1972; Young, 1976). The predominance of eolian sand-sheet deposition at the top of the Chinle in western Colorado supports the interpretation that, as in the Four Corners region, climate became significantly drier at the close of Chinle deposition. Because the Chinle in western Colorado is unconformably overlain by the Middle Jurassic Entrada Sandstone, inferences cannot be drawn about the advent of the Early Jurassic climate in this region.

\section{Paleoclimatic Implications of Depositional Environments}

Several lines of sedimentologic evidence discussed in the preceding sections bear on the interpretation of climate during Chinle deposition. The vertical succession of lith- 
ofacies assemblages and their interpreted depositional environments provide a depositional model characterized by fluvial, deltaic, and lacustrine systems. The progression from fluvial systems in the Shinarump Member to a marsh, lake, and delta complex in the Monitor Butte Member and back to fluvial systems in the Moss Back Member points to the expansion and subsequent infilling of large lakes. The overlying succession from fluvial, floodplain, and marsh systems in the Petrified Forest Member to areally extensive lacustrine strata in the Owl Rock Member and then to marginal-lacustrine mudflats and eolian strata in the Church Rock Member, Rock Point Member, and Wingate Sandstone indicates the development of another large lacustrine system and its subsequent demise. Factors controlling these large-scale trends include the rate and locus of tectonic subsidence, rate of sediment supply from tectonic and volcanic sources, and amount and seasonal distribution of precipitation as a reflection of long-term climate.

Smaller-scale variations within lithofacies, such as the numerous climbing ripple and oscillation ripple sequences in the Monitor Butte Member (Dubiel, 1983), variations in lithology and microfossil content of the marsh deposits, and the occurrence of lungfish and decapod burrows in the purple-mottled unit, are evidence of smaller-scale flooding due to episodic variations in climate that affected regional water tables. Widespread wetland marshes and bogs, fossil ferns, and giant horsetails indicate that water was abundant, with water tables near or at the ground surface much of the time. Aside from the actual taxonomy of the plants, their preservation as carbonized remains and sedimentfilled pith casts indicates rapid sedimentation and preservation beneath the water table.

The coloration of the rocks, which reflects hematite development and original organic-carbon content, and the paleosol development, yield additional insight into water table fluctuations and climate. Gray, black, and green rocks of the Monitor Butte Member reflect its high organiccarbon content-the result of rapid sedimentation and preservation in either subaqueous environments or below the water table, removed from the oxidizing effects of the atmosphere. Black, organic-carbon-rich marsh mudstones indicate that water tables must have been consistently near-surface for plant growth and preservation of organic matter. Well-developed paleosols would not be expected in these subaqueous environments. However, episodically flooded floodplains or exposed lacustrine mudflats would be expected to display some effects of pedogenesis. The color-mottling in the Monitor Butte Member is the result of pedogenesis and of bioturbation, both of which are attributed to shallow, fluctuating water tables. The development of singular, isolated carbonate nodules and pseudoanticlines in Chinle tropical floodplain vertisols reflects the seasonal influx of carbonate with precipitation or flooding.

In the Owl Rock Member, low rates of clastic sedimentation under oxygenated lacustrine water columns led to the destruction of organic carbon in that environment. Thus, the precipitation of carbonate-rich sediments and hematite cements resulted in limestone beds and red siltstones, respectively. Similarly, deposition on subaerially exposed or ephemerally wet lacustrine mudflats where organic matter was oxidized produced the red coloration of the Church Rock and Rock Point Members.

Depositional environments, organic-carbon preservation, position and fluctuation in water tables, and fossils and trace fossils provide the following insights into Chinle paleoclimates. Early in the history of Chinle deposition, water was abundant in wetland, lacustrine, and terrestrial environments that supported a variety of aquatic and terrestrial fauna and flora. During deposition of the upper part of the Chinle, extensive lacustrine basins and mudflats persisted, culminating in playa-mudflat and eolian sand-sheet deposition. The inferred depositional environments, ichnofossils, and paleosols suggest that although water was relatively abundant in the system, deposition was punctuated by dry periods. These interpretations support the predictions from paleoclimate models for humid conditions in the western equatorial region of Pangaea due to the reversal of equatorial flow, and they are consistent with Chinle paleobotany and paleontology.

\section{Paleontological Evidence for Chinle Climate}

A diverse flora and fauna is present in the Chinle Formation, with plants, nonmarine aquatic invertebrates, and vertebrates all well represented. These taxa vary in their utility as paleoclimatic indicators, with the plants and invertebrates providing the greatest constraints on climatic inference.

\section{Paleobotanical Evidence}

The Chinle macroflora has been most extensively described by Daugherty (1941) and subsequently by the prolific studies of Ash (e.g., 1967, 1972, 1987). Palynomorphs have been studied by Daugherty (1941), Gottesfeld (1972), and Litwin $(1985,1986)$. The major floral elements consist of ferns, seed ferns, and conifers; at least 50 species are represented. As noted above, divergent opinions on the climate have been offered by the various students of Chinle paleobotany.

Daugherty (1941) was probably the first worker to use biological and geological evidence to assess Chinle paleoclimates. His interpretations called for a subtropical/tropical climate, on the basis of ferns and other species that require abundant moisture, and on the sheer size of the logs preserved. He also argued for a distinct dry season on the basis of growth rings in the logs; pollen with windborne dispersal; extensive, apparently seasonal floodplain sedimentation; and similarity in vegetational physiognomy to modern tropical/subtropical savannas.

Ash $(1967,1972)$ based his paleoclimatic arguments on plant morphology and paleobiogeography, suggesting that the climate during Chinle deposition was humid and tropical, at least during deposition of the lower parts of the Chinle. Ash cited presence of thin cuticles, morphology 
and dorsoventrally-symmetrical distribution of stomata on leaves, leaf shape, and distribution of extant plants related to Chinle taxa as evidence for a tropical, humid climate.

Gottesfeld (1972) studied the paleoecology of the Chinle, primarily focusing on palynology. He inferred a primarily arid climate, marked by increased seasonal moisture and increasing aridity upward toward the contact between the Chinle Formation and the Wingate Sandstone. His evidence cited thick-walled pollen, oxidized sediments, and overlying eolian beds. In addition, he noted the nature and distribution of plant and vertebrate macrofossils as evidence of localized ever-present water, and mild to warm temperatures.

Growth rings in fossil woods can be useful for interpreting paleoclimate (Creber, 1977; Creber and Chaloner, 1984, 1985, 1987; Francis, 1983, 1986), particularly in combination with sedimentological and other floral data (Parrish and Spicer, 1988; Spicer and Parrish, 1990). Apart from noting their presence, however (Gottesfeld, 1972), no analysis of the growth rings in the Petrified Forest trees has been attempted until recently (Ash and Creber, 1990; J.T. Parrish, unpubl.). Tropical woods commonly have no growth rings because of the lack of seasonality in temperature and rainfall (Creber, 1977). Ash and Creber (1990) concluded that the Petrified Forest trees showed no true growth rings, but rather steady and essentially uninterrupted growth, which would be consistent with a tropical (that is, warm) and ever-wet climate.

Independent work on growth rings in Petrified Forest Member trees by one of us (J.T. Parrish, unpubl.) is still underway. However, a number of interesting preliminary results have emerged from this study. In the twenty-two specimens examined to date, variability in growth was extremely high, ranging from no rings in a preserved radius of $26 \mathrm{~cm}$ (field number ( $\mathrm{fn}$ ) 9004012) to 31 rings in a preserved radius of $15.5 \mathrm{~cm}$ (fn 8908127; "preserved radius" refers only to the part of the total radius in which cells were well enough preserved to permit unhindered examination of cell characteristics). Mean sensitivity, which is an index of interannual variation in ring width (and thus of annual growth; Fritts, 1976), range from 0.12 (fn 8908121) to 0.98 (fn 9004013). Trees with mean sensitivities $<0.3$ are considered to have grown in equable conditions with respect to temperature and moisture, whereas mean sensitivities $>0.3$ indicate highly variable growing conditions (Fritts, 1976). Mean sensitivities could be determined for seventeen specimens, of which only two were $<0.3$; seven values were extremely high, that is, $>0.75$. Perhaps more instructive are the high standard deviations in ring width. For example, one specimen had a mean ring width of 0.65 $\mathrm{cm} \pm 0.96 \mathrm{~cm}$ (fn 8908127). Overall, mean ring widths ranged from $0.35 \mathrm{~cm}$ (fn 9004014) to $5.33 \mathrm{~cm}$ (fn 9004006).

Data gathered so far do not indicate a major difference in growth patterns between specimens measured in the lower and upper parts of the Petrified Forest Member. Rings are wider in the trees from the upper Petrified Forest Member; the difference is statistically significant at $\mathrm{P}<$ 0.05 . This difference could result from changes in climatic, hydrologic, taphonomic, and/or biologic processes, and the preliminary nature of these results does not permit distinguishing among these at this time.

Although clearly the one tree with no rings (fn 9004012) grew continuously over the span that could be examined, continuous growth was not the general mode (cf. Ash and Creber, 1990). However, we agree with Ash and Creber (1990) that the rings probably are not always annual (and thus statistics such as standard deviation and mean sensitivity are not meaningful in the usual sense). On the other hand, rings in many specimens, for example, the one with 31 rings in $15.5 \mathrm{~cm}$, could easily be annual growth rings. In any case, the ring characteristics are indicative of a highly variable growth environment, inconsistent with either climatic constancy or genetically controlled biocyclicity. The variability is mostly likely the result of a combination of variable climate and growth-site hydrologic regime. As this is work in progress, we tentatively suggest that the trees that exhibit narrow growth rings provide evidence that water availability fluctuated annually. These trees most likely grew in areas where the water table was close to the limit of root penetration, so that the annual dry season lowered the water table enough to stop growth in those trees. In general, the trees with narrower rings also had more false rings, which are indicative of temporary cessation of growth during the growing season. This would be consistent with greater susceptibility of these trees to environmental perturbation, and the false rings may indicate drier intervals during the wet season. By contrast, trees with wide or no growth rings provide evidence that climate was equable with respect to temperature, but they do not necessarily indicate year-round rainfall. These trees most likely grew close to the water table, along channel margins, and their growth ceased only during the most severe annual droughts, when the water table dropped farther than normal.

\section{Invertebrate Paleontology}

Nonmarine molluscs from the Chinle Formation include unionid bivalves and prosobranch gastropods. The paleoecology of the taxa and the taphonomy of these mollusc assemblages provide limits on the climatic setting during deposition of the host sediments.

Unionid bivalves are infaunal suspension feeders. They burrow in various substrates and maintain contact with the water-sediment interface through very short siphon tubes. Modern diverse associations of unionids require fresh, non-turbid, oxygenated, shallow, calcium-rich, permanent subaqueous habitats with flowing water, $\mathrm{pH}$ greater than seven, stable substrate, food source, and at least seasonally warm temperatures (Hanley, 1976; Burkey, 1973). Several instances of unionid bivalve survival by aestivation during desiccation of their habitat in dry seasons have been documented (Boss, 1974; Dance, 1958; McMichael, 1952); however, the abundance and diversity of Chinle unionid-bearing beds and absence of bivalve aestivation trace fossils in aquatic Chinle strata suggest that the above-mentioned general requirements of unionid bivalves also apply to the Late Triassic unionid associations. 
Prosobranch gastropods from the Chinle Formation represent two families, Pila (Valvata) gregoryi (Robinson, 1915) of the Pilidae and three species of Lioplacodes (Triasamnicola) of the Viviparidae. These gastropods are herbivorous, grazing on macrophytes or aufwuchs (aquatic scum-biota of algae, bacteria, fungi, protozoans, and associated microscopic plants and invertebrates). These mesogastropods respire subaqueously via a ctenidial gill and require oxygenated habitats, although they can tolerate short periods in anoxic conditions (Aldridge, 1983).

Most Late Triassic unionid bivalve localities in the Chinle Formation are preserved within crevasse-splay deposits (Good, 1989a, b; Parrish and Good, 1987; Good et al., 1988; Dubiel et al., 1989b). Crevasse-splay accumulations typically feature disarticulated valves, current-stable orientations, variable density, and size-sorted assemblages with some degree of fragmentation and abrasion. Unionid bivalve-bearing beds are laterally restricted, rarely exceed 1 $m$ in thickness, and occur within finer grained overbank sequences. Crevasse splays form during high discharge flood events when the river breaches its banks and floods the adjacent floodplain. Flow outside the channel becomes unconfined, resulting in a rapid decrease in flow velocity away from the channel. The coarsest fraction of the sediment load, including the unionid valves, is deposited near the channel in the proximal part of the crevasse splay.

Lacustrine bivalve localities have been identified from the Monitor Butte and Petrified Forest Members of the Chinle Formation in southeastern Utah (Parrish and Good, 1987), and from Petrified Forest Member equivalents in southwestern Colorado (Dubiel et al., 1989b). These localities commonly contain unionid bivalves, prosobranch gastropods, ostracodes, and aquatic vertebrate elements. Taphonomic features of these assemblages include articulation of a significant proportion of the bivalve shells, poor size sorting, and little or no abrasion and fragmentation of bivalve shells. Features that suggest the lakes were perennial include the large size of individuals, the diversity and abundance of the molluscs, lack of bivalve aestivation trace fossils, presence of Darwinula sp. ostracods (Dubiel, 1983; Kietzke, 1989), and the diverse, predominantly articulated vertebrate fauna that includes fish, amphibian, and small reptile elements.

Growth bands in bivalve shells provide evidence for seasonality in molluscan aquatic habitats. Most research to date has examined marine bivalve species. Microgrowth increments are produced by changes in the ratio of calcium carbonate to organic matter within the shell. During optimal environmental conditions, bivalves actively pump water from the overlying water column. Respiration is aerobic, and inorganic shell material, calcium carbonate, is deposited. When environmental conditions decline the valves close, isolating the bivalve from the surrounding environment until conditions improve. Respiration proceeds along anaerobic pathways, and organic-acid waste products accumulate and are stored in extrapallial fluids where they are neutralized by the dissolution of shell calcium carbonate. Thus, the dissolution produces a layer of insoluble organic residue on the inner shell surface. When the bivalve resumes active pumping with the improvement of environmental conditions, deposition of calcium carbonate shell material resumes, preserving the organic layer as a record of the time of shell closure (Lutz and Rhodes, 1980).

Growth banding in freshwater bivalves has been attributed to annual-scale climate cycles, called annual bands, and random events, called pseudoannual bands (Coker et al., 1922; Tevesz and Carter, 1980b). Annual bands feature thin, dark-colored, slower growth increments separated by thick, light-colored normal growth increments. Annual bands are produced in temperate climates by hibernation, resulting in sustained valve closure during the winter season (Coker et al., 1922; Negus, 1966), and in tropical climates either by aestivation during dry season loss of habitat due to desiccation of lacustrine or fluvial environments (McMichael, 1952) or by prolonged growth interruptions due to high turbidity during storms typical of a monsoonal climate (Tevesz and Carter, 1980a). Pseudoannual bands are relatively thin, incompletely developed around the entire shell perimeter, variable in color and texture, and lack regular spacing or periodicity (Stansbery, 1961; Tevesz and Carter, 1980b). Pseudoannual bands are produced by any event that forces the bivalve to suspend pumping and isolate itself from the overlying water column by closing its valves, such as attempted predation or turbidity produced by isolated storms. Pseudoannual dark increments are much thinner than true annual dark increments due to the shorter duration of pseudoannual events. Growth bands are studied by microscopic examination of thin sections of shells or by examination of external shell surfaces.

Chinle Formation unionid shells from the Monitor Butte, Moss Back, Petrified Forest, and Owl Rock Members throughout the depositional basin exhibit three patterns of growth banding in well-preserved specimens: regular, irregular, and massive (Table 3). Regular banding features light and dark bands of near-equal widths with sharp boundaries (Fig. 9A). Several localities contain specimens with this banding pattern clearly preserved on the external surface of shells (Fig. 9B). Irregular banding features light and dark bands of irregular thickness (Fig. 9C). The irregular banding pattern occurs in several lacustrine bivalve assemblages. Modern lacustrine unionids typically have distinct and regularly spaced annual bands and paucity of pseudoannual bands due to the stabilizing effects of a large body of water (Grier, 1922; Stansberry, 1961). Lacustrine systems inhabited by these Chinle bivalves perhaps were too small or shallow to provide protection from environmental perturbations. Massive banding features rare, very thin, irregularly spaced dark bands in generally very thick, heavy shells (Fig. 9D), apparently due to continuous growth. Neomorphosed texture reflects recrystalization and concomitant obliteration of any preexisting growth band pattern.

The regular banding pattern represents annual growth bands in Chinle Formation unionid bivalves, reflecting annual environmental variations or seasons. Because the Colorado Plateau was within the tropics during the Late Triassic, annual temperature variation was insufficient to force 

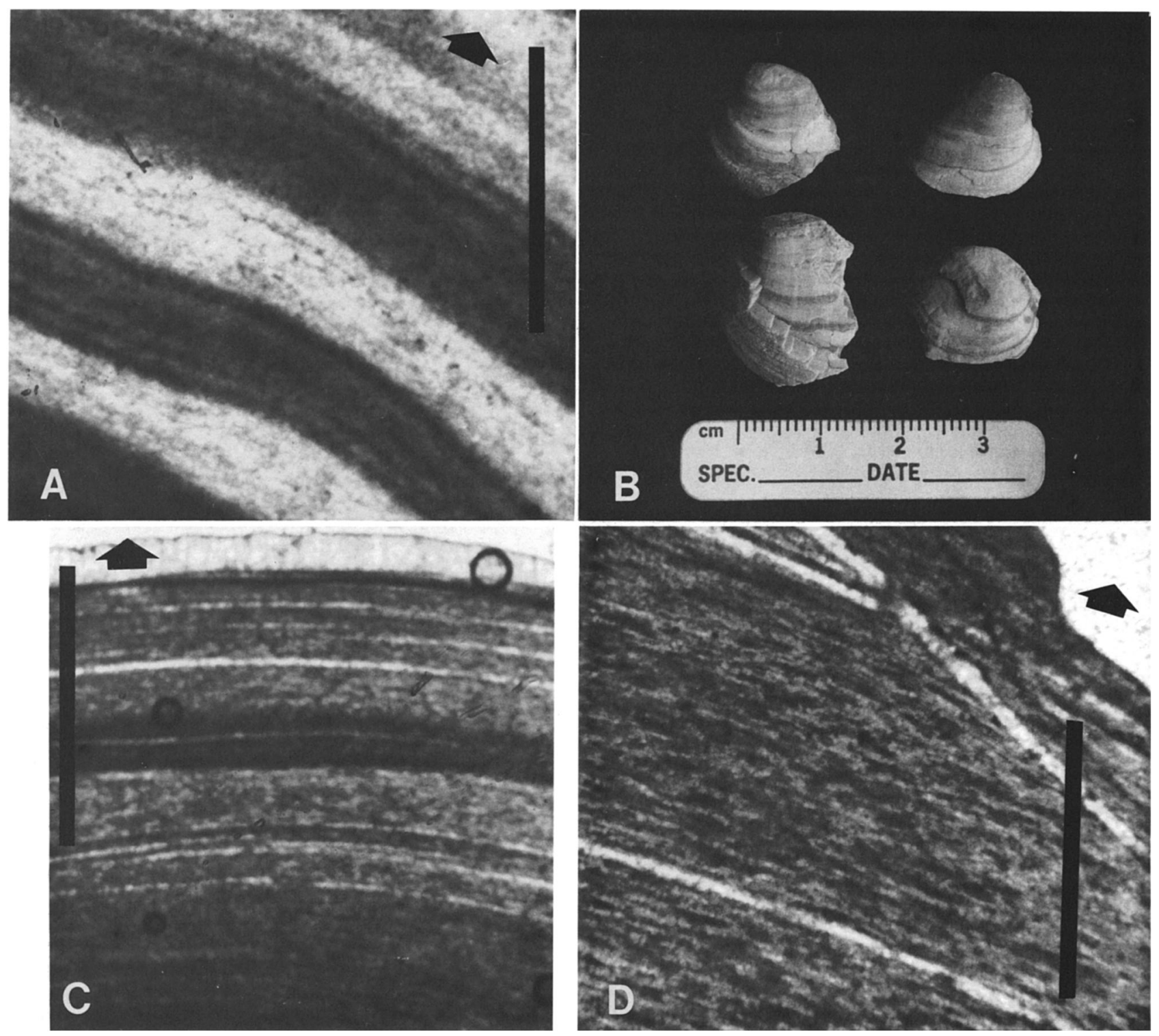

FIGURE 9-Examples of growth bands in Chinle Formation molluscs. A. Photomicrograph showing regular banding of light and dark layers in sample from Round Rock 8-87. B. Photograph showing exterior color banding on bivalves in sample from PF29-84. C. Photomicrograph showing irregular banding in sample from No Name Mesa. D. Photomicrograph showing massive banding in sample from Cameron. Scale bars in photomicrographs are $0.5 \mathrm{~mm}$; arrows point toward exterior of shell.

hibernation and produce cold-temperature annual growth bands. Aestivation is not supported as a cause of regular banding because of the absence of bivalve aestivation trace fossils in the Chinle, the high diversity and abundance of unionids, and the sedimentological and vertebrate paleontological evidence of perennial fluvial systems. High turbidity during a prolonged storm season is the most likely cause of Chinle unionid annual growth bands. The abundant crevasse-splay accumulation of unionid valves indicate high-discharge flood events of the type that would result from storm runoff. Such runoff could indicate perennial or intermittent fluvial systems, however, fluvial sedimentology and molluscan abundance and diversity indicate that at least the larger streams and lakes were perennial.

\section{Vertebrate Paleontology}

Vertebrate studies within the Chinle Formation date back to the 1860 's but only recently have been used extensively for paleoclimatic inferences. For the most part, the Chinle fauna is a cosmopolitan one, with many of the same genera occurring in correlative sedimentary rocks in Europe and in the Newark Supergroup (e.g., Sues and 
TABLE 3-Locality, depositional setting, and banding pattern in Chinle Formation molluscs.

\begin{tabular}{|c|c|c|c|c|}
\hline Locality & State & Member & Environment & $\begin{array}{l}\text { Banding } \\
\text { pattern }\end{array}$ \\
\hline PF29-84 & $\mathrm{AZ}$ & Petrified Forest Member & Crevasse splay & regular \\
\hline PF7-84 & $\mathrm{AZ}$ & Petrified Forest Member & Crevasse splay & massive \\
\hline PF14-84 & $\mathrm{AZ}$ & Petrified Forest Member & Crevasse splay & $\begin{array}{l}\text { neomor- } \\
\text { phosed }\end{array}$ \\
\hline PF38-85 & $\mathrm{AZ}$ & Petrified Forest Member & Crevasse splay & $\begin{array}{l}\text { neomor- } \\
\text { phosed }\end{array}$ \\
\hline PF18-84 & $\mathrm{AZ}$ & Petrified Forest Member & Crevasse splay & irregular \\
\hline PF12-84 & $\mathrm{AZ}$ & Petrified Forest Member & Crevasse splay & $\begin{array}{l}\text { neomor- } \\
\text { phosed }\end{array}$ \\
\hline $\begin{array}{l}\text { Round Rock } \\
\text { 8-87 }\end{array}$ & $\mathrm{AZ}$ & Petrified Forest Member & Crevasse splay & regular \\
\hline Cameron & $\mathrm{AZ}$ & Petrified Forest Member & Crevasse splay & massive \\
\hline MNA-360 & $\mathrm{AZ}$ & Owl Rock Member & Crevasse splay & irregular \\
\hline Hillside Mine & UT & Moss Back Member & Crevasse splay & $\begin{array}{l}\text { neomor- } \\
\text { phosed }\end{array}$ \\
\hline $\begin{array}{l}\text { No Name } \\
\text { Mesa }\end{array}$ & UT & Monitor Butte Member & Lacustrine & irregular \\
\hline
\end{tabular}

Olsen, 1990) on the east coast of the United States. For some families, closely related genera are also known from slightly older or younger beds in India, Morocco, and South America.

By far the most abundant vertebrate skeletal fossils in the Chinle belong to phytosaurian archosaurs and metoposaurid amphibians, both of which were amphibious to aquatic. The distribution, preservation, and environments of deposition of fossils of these groups are consistent with the presence of perennial streams, lakes, and ponds (Colbert, 1972; Gottesfeld, 1972; Parrish, 1989). Certainly the presence of large aquatic ectotherms such as the metoposaurids suggests temperate to tropical conditions, but these organisms do not seem to be useful for more precise temperature inferences.

Large, fully terrestrial vertebrates were also present throughout deposition of the Chinle. Herbivorous forms included the abundant, armored aetosaurs, as well as trilophosaurs, rhynchosaurs, and rare ornithischian dinosaurs. Generic-level extinctions of aetosaurs, and wholescale extinction of rhynchosaurs, trilophosaurs, and the semi-aquatic herbivorous dicynodonts appear to have occurred at or near the Carnian-Norian boundary (Parrish, 1986, 1989). Fully terrestrial carnivores included the poposaurs, crocodylomorphs, and staurikosaurid and podokesaurid dinosaurs. These were not clearly subject to generic or higher level extinctions at the Carnian-Norian boundary, although abundance and diversity of dinosaurs appears to increase in the Norian. In any event, the characterization of Chinle faunas offered by Stewart et al. (1972), which called for increased abundance of aquatic forms during the later part of Chinle deposition, is not supported in light of new collections and abundance estimates based on previous collections (Parrish, 1989). Locally, the abundance of large obligate aquatic vertebrates, such as lungfishes and coelacanths (Schaeffer, 1967; Ash, 1978; Dubiel, 1987b; Dubiel et al., 1987), indicates the presence of large, perennial watercourses or lakes and marshes.

In some situations, the preservation of vertebrate fossils suggests climatic seasonality (Parrish, 1989). For example, the nature of skeletal preservation in the Placerias Quarry near St. Johns, Arizona indicates the following taphonomic sequence: 1 ) animals died in situ and were disarticulated but not disassociated subaqueously or subaerially; 2) some elements were trampled and partially buried, with exposed sections of elements subject to decay (Camp and Welles, 1956); and 3) bones were subsequently preserved by additional sediment influx. The nature of the quarry strata suggests an organic-rich, possibly partially anoxic pond, whereas the nature of the preservation, particularly the evidence of trampling, suggests periodic, possibly seasonal fluctuations in water table.

Similarly, the Coelophysis quarry near Ghost Ranch, New Mexico (Schwartz and Gillette, 1986) appears to be a mass death concentration, presumably produced by a herd drowning (Parrish, 1989). However, the vertisolic nature of the entombing strata and the mode of preservation of the skeletons (with necks recurved as a result of drying of the nuchal ligaments) suggests that the animals accumulated on a floodplain and that the carcasses dried out prior to being buried by a subsequent massive influx of sediment, perhaps from a mudflow.

Trace fossils are also good indicators of seasonality. Dubiel et al. (1987) described burrows from various horizons 
in the Chinle that were consistent in morphology with burrows containing fresh water lungfish fossils known from various upper Paleozoic rocks in North America (e.g., Langston, 1963; Vaughn, 1964; Carroll, 1965; Carlson, 1968). Identification of these burrows as all belonging to lungfish has been questioned (Dubiel et al., 1988; McAllister, 1988), and some similar burrows from the Chinle of Utah are associated with decapod crustaceans (crayfish) (Dubiel et al., 1989a; Hasiotis and Mitchell, 1989). However, the decapod burrows are smaller in diameter and different in surficial morphology from the large burrows described by $\mathrm{Du}$ biel et al. (1987) and Dubiel et al. (1989a).

The apparent lungfish burrows predominantly occur in clusters adjacent to fluvial channels or the edges of lacustrine deposits throughout the Chinle Formation. The high density of burrows and the high incidence of intersecting and crosscutting burrows suggests that the same sites were repeatedly burrowed by similar organisms. Modern lepidosirenid-lungfish burrow in response to local desiccation, most commonly in association with lowering of the water table. In comparison, the Chinle crayfish burrows are as long as $2 \mathrm{~m}$, and closely resemble modern crayfish burrows, which typically are deepened to permit the crayfish in the bottom of the burrow to remain below the water table when it falls in the dry season. This apparently cyclic lungfish burrowing pattern, the very deep crayfish burrows, coupled with the mottled or gleyed character of the enclosing paleosols, is consistent with a model of a fluctuating water table, as would be expected with strong seasonality.

Upper Triassic continental rocks are distributed worldwide, with extensive sequences in South America, Europe, North and South Africa, India, China, and Southeast Asia. As would be expected on the single Pangaean supercontinent, the vertebrate assemblages are quite similar at correlative levels and facies between Europe, North Africa, India, and North America. South American faunas and the rather fragmentary vertebrate record of the Upper Triassic of South Africa show substantial differences from the more northern assemblages, predominantly in the absence of phytosaurs and metoposaurs from the southern localities and the presence of ecologically similar clades that are apparently endemic - the Proterochampsidae are archosaurs with some morphological similarities to phytosaurs, and Chitiguisauridae are a group of stereospondyl amphibians that are apparently the closest relatives to $\mathrm{Me}$ toposauridae.

\section{DISCUSSION}

The climate of Pangaea was described by Robinson (1973) as monsoonal, and this description was supported by Parrish et al. (1986), who produced conceptual climate models that demonstrated qualitatively the mechanisms of the Pangaean monsoon. As Pangaea moved north and the exposed land area was distributed more evenly on either side of the equator (Parrish, 1985), the seasonality would be expected to have become stronger and the equatorial region (and mid-latitude continental interiors) drier, until the Triassic. In the Triassic, the monsoonal circulation would have been at maximum strength (Parrish and Peterson, 1988), and, depending on topography, aridity of the continental interior would have been greatest.

The few eolian sandstones deposited on the Colorado Plateau during the Late Triassic show a change in wind direction to westerly or northwesterly from the predominantly northerly or northeasterly winds of the rest of the Pangaean interval (except the Late Jurassic, when the Colorado Plateau sector of Pangaea had moved far enough north to be in the belt of the westerlies (Peterson, 1988). Parrish and Peterson (1988) suggested that the proposed Pangaean monsoonal circulation became strong enough at that time to influence circulation on the western side of Pangaea and draw moisture along the equator from the west.

Compared with the rest of the Pangaean interval, the Chinle Formation represents an unusually wet episode on the Colorado Plateau during the Pangaean interval. The Chinle consists principally of fluvial, floodplain, marsh, and lacustrine deposits, with only minor eolian and playa settings at the close of Chinle deposition (Dubiel, 1989a). By contrast, eolian strata, playa deposits, and evaporites were widespread both before and after Chinle deposition (Parrish and Peterson, 1988). The contrast between the Chinle Formation and preceding and succeeding deposition, coupled with evidence for abundant and diverse vegetation, has resulted in interpretations of the Chinle Formation as representing a humid, tropical environment (Ash, 1967, 1972; Ash and Creber, 1990). However, despite the evidence for humidity, a suggestion persists in the paleobotanical literature that the Chinle somehow also represented an arid environment (Daugherty, 1941; Gottesfeld, 1972). The explanation for such widely divergent interpretations, both supported by substantial evidence, must be a strong episodicity of rainfall and high water tables in lowland settings. The interpretations also reflect, in part, an earlier pervasive belief that all redbeds are indicative of arid or semi-arid origins (e.g., Gottesfeld, 1972). No controversy exists with regard to Chinle paleotemperatures. The preponderance of evidence favors an interpretation of consistently warm temperatures year-round, although some seasonal variation in temperature cannot be ruled out.

An interpretation of abundant moisture during deposition of the Chinle near the west coast of Pangaea is supported by the existence of organic-rich lacustrine, bog, and marsh deposits and the abundant gleyed paleosols, especially in the Monitor Butte and lower part of the Petrified Forest Members. Although the trees were large and apparently abundant, this does not represent de facto evidence for high rainfall. Evidence for episodicity of rainfall is strong in the Chinle and includes gleyed, calcic, and especially vertic paleosols, pseudoanticlines in paleosols, intersecting mudcracks, slickensided soil peds, lungfish and decapod burrows, desiccation of vertebrate remains followed by rapid burial, and sedimentological evidence for fluctuations in surficial hydrological regime. Lacustrine laminae of clay and limestone also argue for seasonality of rainfall. The presence of growth rings in the woods and 
annual growth bands in the unionids also suggests a seasonality or episodic interruption of growth.

The climatic effects of Pangaean geography have recently been investigated with numerical models by Crowley et al. (1989) and Kutzbach and Gallimore (1989). Crowley et al.'s (1989) models were directed principally toward examining temperature distribution geographically and temporally, and thus can be used only indirectly to interpret variations in rainfall. Their simulations generated strong seasonality of temperature in southern Pangaea during the early Late Permian (when more land was present in the southern hemisphere than in the northern hemisphere), similar to the results of Kutzbach and Gallimore (1989). The annual range of temperature for the equatorial regions, and the Colorado Plateau in particular, was predicted to have been less than $5^{\circ} \mathrm{C}$. However, the strong seasonal temperature contrast in the southern hemisphere would almost certainly have resulted in monsoonal conditions. The predicted cross-equatorial temperature contrast ranged from $20^{\circ} \mathrm{C}$ in the northern winter to $50^{\circ} \mathrm{C}$ in the northern summer, although in the latter case, the thermal maximum was only slightly north of the equator (Crowley et al., 1989, fig. 1).

Crowley et al. (1989) ran a sensitivity test for the docking of Laurussia and Gondwana to evaluate the relative importance of this change in geography to the establishment of seasonal conditions. The collision resulted in a slight increase of southern hemisphere maximum temperatures. The slight northward movement of Pangaea between the Late Carboniferous and mid-Permian resulted in no change, principally because the amount of land in the southern hemisphere did not change (Crowley et al., 1989). The slight increase in summer temperatures with docking suggests that seasonality would increase with continued northward movement of Pangaea and more even distribution of land between the two hemispheres. This is borne out in a general way by the results of Kutzbach and Gallimore (1989). The latitudinal temperature gradient is stronger in their simulations, with Pangaea symmetrically disposed about the equator. However, a comparison between the model results of Kutzbach and Gallimore (1989) and Crowley et al. (1989) can be made only cautiously because: (1) the models used are quite different (energybalance (EBM) versus global circulation (GCM) models), (2) the GCM used by Kutzbach and Gallimore (1989) predicts colder winters than observed for the modern, and (3) Crowley et al.'s (1989) maps are January and July (maximum winter and summer) means whereas Kutzbach and Gallimore's (1989) are three-month winter and summer means (December-January-February and June-July-August, respectively). The results of both modelling exercises are consistent with each other in predicting an extremely wide mean annual range of temperature, $50^{\circ} \mathrm{C}$ (Crowley et al., 1989, fig. 2; Kutzbach and Gallimore, 1989, fig. 6). Maximum summer temperatures in both models for the approximate region of the Colorado Plateau are $20-25^{\circ} \mathrm{C}$.

Model results of Kutzbach and Gallimore (1989) confirm the hypothesis of strong monsoonal circulation over Pangaea suggested by the conceptual model (Robinson, 1973;
Parrish et al., 1982, 1986) and EBM (Crowley et al., 1989) results. Because their simulations used a highly idealized Pangaean geography and lacked topography, Kutzbach and Gallimore (1989) cautioned against using the model results for detailed comparisons. Nevertheless, the results may be regarded as suggestive. Most importantly in the context of the present discussion, the annual precipitation-evaporation balance was negative for the region encompassing the Colorado Plateau in four different simulations. Precipitation from eastward-flowing, low-latitude winds was seasonal, as predicted by Parrish and Peterson (1988) based on the conceptual model of Parrish and Curtis (1982).

Perhaps one of the most intriguing aspects of Kutzbach and Gallimore's (1989) results is the continuous band of precipitation extending across Pangaea at about $10-15^{\circ} \mathrm{N}$ during the northern summer. Similar apparent increases in moisture to those represented by the Chinle on the Colorado Plateau have been documented or suggested for New Brunswick, the North Sea, and Israel (Simms and Ruffell, 1989, in press), along a line roughly parallel to the band of precipitation predicted in Kutzbach and Gallimore's (1989) simulations. However, preliminary examinations (J.M. Parrish, unpubl.) suggest that sedimentary regimes and types of soils formed are quite similar worldwide during the Carnian-Norian, with one notable exception being the interbedded eolian and fluvial deposits of the Carnian Lossiemouth Sandstone in Scotland (Benton and Walker, 1985). The trend in the Chinle towards increasingly oxidized strata through the Norian is also observed in Germany, South Africa, and South America. Similarly, the shift from primarily fluvial-lacustrine to predominantly eolian deposition near the Triassic-Jurassic boundary is observed in South Africa as well as on the Colorado Plateau. The apparently anomalous pattern of perennial fluvial-lacustrine sedimentation throughout the Triassic-Early Jurassic in the Newark Supergroup has been attributed by Hay et al. (1982) to the local influence of mountain ranges produced by rifting.

The widespread apparent increase in precipitation (or decrease in evaporation) may require a more complex explanation than simply the reversal of equatorial flow suggested by Parrish and Peterson (1988). One possibility is suggested by Kutzbach and Gallimore's (1989) sensitivity test for a five-fold increase in $\mathrm{CO}_{2}$ (which was coupled to a realistic $1 \%$ decrease in solar luminosity; see also Parrish, 1985), which resulted in an increase in temperature and temperature range and a slight decrease in precipitationevaporation balance. A slight lowering of $\mathrm{CO}_{2}$ in the atmosphere might have had the opposite effect, producing the effects seen in the Carnian-Norian.

Sedimentological and paleontological evidence strongly suggests that rainfall throughout Chinle deposition was episodic. The precipitation-evaporation balance apparently dropped during deposition of the Rock Point Member, so that the overall climate became drier. We have until this point intentionally avoided emphasizing the term "seasonal," which would imply annual variation in rainfall, because "episodic" simply implies variable rainfall without implying a particular periodicity. In practice, it might be 
possible to distinguish between seasonal and merely episodic rainfall in this environment. Because the growth of tropical woods is not controlled by a strong annual signal, interruptions of growth could be controlled entirely by aperiodic environmental factors (Ash and Creber, 1990). Such factors would be expected to give rise to highly irregular growth sequences in all the woods and especially in the invertebrates. That the growth variations in the invertebrates are relatively regular, as are the growth rings in many of the woods examined to date (J.T. Parrish, unpubl.), speaks against this alternative interpretation. Moreover, the clastic-carbonate couplets in laminated Owl Rock Member limestones suggest that precipitation and runoff to the lake may well have been seasonal, at least at times.

The climatic analysis of the Colorado Plateau eolian sandstones by Parrish and Peterson (1988), on which some of the conclusions presented here are predicated, was based on reconstructions of continental positions by Ziegler et al. (1983); their reconstruction for the earliest Triassic is shown schematically in Figure 1. Recent work on the Late Triassic and Jurassic parts of the North American apparent polar wander path (APWP) indicates that the continental reconstructions, and therefore the atmospheric circulation models (e.g., see discussion in Parrish et al., 1982), should be reconsidered. Recent APWPs have been derived from paleomagnetic data from rocks in western (May and Butler, 1986; Ekstrand and Butler, 1989; Bazard and Butler, in press) and eastern (Witte and Kent, 1989, 1990) North America. Although the conclusions about the North American APWP by these authors conflict on some points, they agree that North America, and therefore the Colorado Plateau, were slightly farther south in the Late Triassic and Early Jurassic than reconstructed by Ziegler et al. (1983) and Denham and Scotese (1988), perhaps by as much as $10^{\circ}$ latitude. A reconstruction by Bazard and Butler (in press), based in part on data from the Owl Rock Member of the Chinle Formation, is shown in the inset in Figure 1.

Using the paleogeography of the Pliensbachian Age (Early Jurassic) presented by Ziegler et al. (1983) and Pliensbachian continental positions based on Bazard and Butler's (in press) paleomagnetic analysis, we produced a revised conceptual model of Pliensbachian atmospheric circulation. A detailed analysis of the climate patterns resulting from this new model is outside the scope of this paper and will be presented elsewhere. However, although Bazard and Butler's (in press) reconstructions have major implications for the Late Triassic and Early Jurassic climates of Eurasia and southeastern Pangaea, the difference in latitude and rotation of the Colorado Plateau region, compared with Ziegler et al.'s (1983) reconstruction, is small enough to have little effect on the interpretations presented here and by Parrish and Peterson (1988). The principal effect is on the timing of the monsoon maximum. The relatively slow rotation and northward drift of Pangaea indicated by Ziegler et al.'s (1983) and Denham and Scotese's (1988) reconstructions for the Triassic meant that conceptual climate models alone could not predict when during the Triassic the monsoon maximum was likely to have occurred. Conceptual climate models based on Bazard and Butler's (in press) reconstructions, however, show that the monsoon maximum was most likely to have occurred during the Early Triassic. However, this again has stronger implications for the climate of northeastern and southeastern Pangaea than for the equatorial region, because the Pangaean monsoon would have affected the equatorial regions for a much longer period than the outlying regions.

The preponderance of evidence worldwide as well as within the Chinle suggests that the Triassic climate consisted of a "megamonsoon" (Kutzbach and Gallimore, 1989) and that rainfall was therefore probably strongly seasonal. Total rainfall must have been relatively high, in order to explain the high water tables that would have had to exist to support perennial lakes and marshes, lush vegetation through dry periods, and to give rise to the observed Chinle paleosol profiles. This is consistent with monsoonal climate and vegetation.

\section{ACKNOWLEDGMENTS}

We thank T.M. Bown and F. Peterson, U.S. Geological Survey, and two anonymous journal reviewers for critical comments on this manuscript. We have benefitted from discussions with P.E. Olsen, S.R. Ash, G.T. Creber, J. Quade, D.R. Bazard, and R.F. Butler; thanks to D.R. Bazard and R.F. Butler for permission to use their Owl Rock reconstruction. This research was partly funded by $\mathrm{Na}$ tional Science Foundation Grant EAR-89035449 to J.T. Parrish and by National Geographic Research Grant 335286 to J.M. Parrish, S.C. Good, and R.F. Dubiel. Dubiel's research is supported by the Evolution of Sedimentary Basins Program of the U.S. Geological Survey. Parts of this research are the product of individual research efforts by each author in Petrified Forest National Park, Arizona; we thank Superintendent Gary Cummins, Naturalist Carl Bowman, and former Superintendents Roger Rector and Ed Gastellum for their hospitality, technical assistance, and support. Field work in Petrified Forest National Park, Arizona was funded in part by research grants to each author from the Petrified Forest Museum Association; we thank Dwayne Cassidy, Executive Director of the Petrified Forest Museum Association, for funding, encouragement, and logistical support for this research.

\section{REFERENCES}

Aldridge, D.W., 1983, Physiological ecology of freshwater Prosobranch: in Russell-HunTer, W.D., The Mollusca, Ecology, v. 6, Academic Press, p. 329-358.

Ash, S.R., 1967, The Chinle (Upper Triassic) megaflora, Zuni Mountains, New Mexico: New Mexico Geological Society, 18th Annual Field Conference Guidebook, 125-131.

AsH, S.R., 1972, Plant megafossils in the Chinle Formation: in BreEd, C.S., and BREED, W.J., eds., Investigations in the Triassic Chinle Formation: Museum of Northern Arizona Bulletin 47, p. 23-44.

AsH, S.R., 1978, Geology, paleontology, and paleoecology of a Late Triassic lake, western New Mexico: Brigham Young University Geology Studies, v. 25, pt. 2, 100 p. 
AsH, S.R., 1987, The Upper Triassic red bed flora of the Colorado Plateau, western United States: in Morales, M., and ElliotT, D.K., eds., Triassic Continental Deposits of the American Southwest: Journal of the Arizona-Nevada Academy of Science, v. 22, p. $95-105$.

Ash, S.R., Litwin, R.J., and Traverse, A., 1982, The Upper Triassic fern Phlebopteris smithii (Daugherty) Arnold and its spores: Palynology, v. 6, p. 202-219.

Ash, S.R., and Creber, G.T., 1990, Paleoclimatic interpretation of the wood structure of the trees in Petrified Forest National Park, Arizona: A progress report: Geological Society of Anierica, Cordilleran Section, Abstracts with Programs, v. 22, p. 4.

BAZARD, D. R., and Butler, R. F., in press, Paleomagnestism of the Chinle and Kayenta Formations, New Mexico and Arizona: Journal of Geophysical Research.

Benton, M.J., and WALKER, A.D., 1985, Palaeoecology, taphonomy, and dating of Permo-Triassic reptiles from Elgin, North-east Scotland: Palaeontology, v. 28, p. 207-234.

BlaKey, R.C., and Gubitosa, R., 1983, Late Triassic paleogeography and depositional history of the Chinle Formation, southern Utah and northern Arizona: in ReYnolds, M.W., and Dolly, E.D., eds. Mesozoic Paleogeography of West Central United States: Rocky Mountain Section, Society of Economic Paleontologists and Mineralogists, Rocky Mountain Paleogeography Symposium 2, p. 57 76.

Blakey, R.C., and Gubitosa, R., 1984, Controls of sandstone body geometry and architecture in the Chinle Formation (Upper Triassic), Colorado Plateau: Sedimentary Geology, v. 38, p. 51-86.

BlodgetT, R.H., 1988, Calcareous paleosols in the Triassic Dolores Formation, southwestern Colorado: Geological Society of America Special Paper 216, p. 103-121.

BorcherT, H., and MuIR, R., 1964, Salt deposits-the origin, metamorphism, and deformation of evaporites: Van Nostrand C., Ltd., London, $338 \mathrm{p}$.

Boss, K.J., 1974, Oblomovism in the Mollusca: Transactions of the American Microscopic Society, v. 93, p. 460-481.

Bown, T.M., Kraus, M.J., and Middleton, L.T., 1983, Triassic fluvial systems, Petrified Forest National Park, Arizona: (Abst.) Symposium on Southwestern Geology and Paleontology, Museum of Northern Arizona, 1 p.

Briden, J.C., and Irving, E., 1964, Paleolatitude spectra of sedimentary paleoclimate indicators: in Nairn, A.E.M., ed., Problems in Paleoclimatology: Wiley, London, p. 199-224.

Busby-Spera, C., 1988, Speculative tectonic model for the early Mesozoic arc of the southwest Cordilleran United States: Geology, v. 16 , p. 1121-1125.

Burkey, A.J., 1973, Physiological ecology of freshwater bivalves: in Russell-Hunter, W.D., ed., The Mollusca, Ecology, v. 6: Academic Press, p. 281-327.

CAMP, C.L., and Welles, S.P., 1956, Triassic dicynodont reptiles: Memoirs of the University of California, v. 13, p. 255-348.

CARLSON, K.J., 1968, The skull morphology and estivation burrows of the Permian lungfish Gnathorhiza serrata: Journal of Paleontology, v. 76, p. 641-663.

CARRolL, R.L., 1965, Lungfish burrows from the Michigan Coal Basin: Science, v. 148, p. 963-964.

Coker, R.E., Shira, A.F., Clark, H.W., and Howard, A.D., 1922, Natural history and progation of freshwater mussels: Bulletin of the Bureau of Fisheries, v. 37, p. 75-181.

ColberT, E.H., 1972, Vertebrates from the Chinle Formation: Museum of Northern Arizona Bulletin, v. 47, p. 1-11.

Creber, G.T., 1977, Tree rings: A natural data-storage system: Biological Reviews, v. 52 , p. $349-383$.

Creber, G.T., and Chaloner, W.G., 1984, Climatic indications from growth rings in fossil woods, in BRENCHLEY, P.J., ed., Fossils and Climate: John Wiley and Sons, New York, p. 49-74.

Creber, G.T., and Chaloner, W.G., 1985, Tree growth in the Mesozoic and early Tertiary and the reconstruction of paleoclimates:
Palaeogeography, Palaeoclimatology, and Palaeoecology, v. 52, p. $35-60$.

Creber, G.T., and Chaloner, W.G., 1987, The contribution of growth ring studies to the reconstruction of past climates, in WARD, R.G.W., ed., Applications of Tree Ring Studies: Oxford, BAR International Series 333, p. 37-67.

Crowley, T.J., Hyde, W.T., and ShorT, D.A., 1989, Seasonal cycle variations on the supercontinent of Pangaea: Implications for Early Permian vertebrate extinctions: Geology, v. 17, p. 457-460.

DANCE, S.P., 1958, Drought resistance in an African freshwater bivalve: Journal of Conchology, v. 24, p. 281-283.

DAs, P.K., 1986, Monsoons, Fifth IMO Lecture: World Meteorological Organization, v. No. 163, 155 p.

Daugherty, L.H., 1941, The Upper Triassic flora of Arizona: Carnegie Institute of Washington Publication 526, 108 p., 34 plates.

Denham, C.R., and Scotese, C.R., 1988, Terra Mobilis@i: A Plate Tectonic Program for the Macintosh ${ }^{\circledR}$.

Dickinson, W.R., 1981, Plate tectonic evolution of the southern Cordillera, in Dickinson, W.R., and PaYne, W.D., eds., Relations of Tectonics to Ore Deposits in the Southern Cordillera: Arizona Geological Society Digest, v. 14, p. 113-135.

Dubiel, R.F., 1983, Sedimentology of the lower part of the Upper Triassic Chinle Formation, southeastern Utah: U.S. Geological Survey Open-File Report 83-459, 48 p.

Dubiel, R.F., 1984, Evidence for wet paleoenvironments, Upper Triassic Chinle Formation, Utah: Geological Society of America, Rocky Mountain Section, 37th Annual Meeting, Abstracts with Programs, v. 16, p. 220.

Dubiel, R.F., 1986, Evolution of a fluvial-lacustrine system: Tectonic and climatic controls on sedimentation of the Upper Triassic Chinle Formation, Colorado Plateau: Geological Society of America, Rocky Mountain Section, 39th Annual Meeting, Abstracts with Programs, v. 18, p. 352 .

DuBIEL, R.F., 1987a, Sedimentology of the Upper Triassic Chinle Formation, southeastern Utah: Ph.D. Dissertation, University of Colorado at Boulder, $132 \mathrm{p}$.

DUBIEL, R.F., 1987b, Sedimentology and new fossil occurrences of the Upper Triassic Chinle Formation, southeastern Utah: in CAMPBELL, J.A., ED., Geology of Cataract Canyon and Vicinity: Four Corners Geological Society, Tenth Field Conference Guidebook, p. 99-107.

Dubiel, R.F., 1987c, Sedimentology of the Upper Triassic Chinle Formation, southeastern Utah-Paleoclimatic implications, in Morales, M., and ElliotT, D.K., eds., Triassic Continental Deposits of the American Southwest: Journal of the Arizona-Nevada Academy of Science, v. 22, p. 35-45.

DUBIEL, R.F., 1988, Rhizoliths and rhizofacies in floodplain paleosols, Upper Triassic Chinle Formation, west-central Colorado: Geological Society of America, Abstracts with Programs, v. 20, p. A264.

DuBiel, R.F., 1989a, Sedimentology and revised nomenclature of the Upper Triassic Chinle Formation and the Lower Jurassic Wingate Sandstone, northwestern New Mexico and northeastern Arizona: in Anderson, O.J., Lucas, S.G., Love, D.W., and Cather, S.M., eds., Southeastern Colorado Plateau: New Mexico Geological Society, 40th Field Conference Guidebook, p. 213-223.

DuBIEL, R.F., 1989b, Depositional and climatic setting of the Upper Triassic Chinle Formation, Colorado Plateau: in LuCAs, S.G., and Hunt, A.P., eds., Dawn of the Age of Dinosaurs in the American Southwest: New Mexico Museum of Natural History, 1989 Spring Field Conference Guidebook, p. 171-187.

DuBIEL, R.F., 1989c, Paleoclimatic cycles and tectonic controls on fluvial, lacustrine, and eolian strata in the Upper Triassic Chinle Formation, San Juan Basin: American Association of Petroleum Geologists Bulletin, v. 73, p. 1153-1154.

Dubiel, R.F., in press, Depositional history of the Upper Triassic Chinle Formation in the Uinta-Piceance and Eagle basins, northwest Colorado and northeastern Utah: U.S. Geological Survey Bulletin 1787, $35 \mathrm{p}$.

Dubiel, R.F., BlodGetT R.H., and Bown, T.M., 1987, Lungfish bur- 
rows in the Upper Triassic Chinle and Dolores Formations, Colorado Plateau: Journal of Sedimentary Petrology, v. 57, p. 512521.

Dubiel, R.F., BlodgetT, R.H., and Bown, T.M., 1988, Lungfish burrows in the Upper Triassic Chinle and Dolores Formations, Colorado Plateau: Comments on the recognition criteria of fossil lungfish burrows: Reply: Journal of Sedimentary Petrology, v. 58, p. 367-369.

Dubiel, R.F., BlodgetT, R.H., and Bown, T.M., 1989a, Lungfish burrows in the Upper Triassic Chinle and Dolores Formations, Colorado Plateau: New evidence suggests origin by a burrowing decapod crustacean: Reply: Journal of Sedimentary Petrology, v. 59 , p. $876-878$.

DuBIEL, R.F., Good, S.C., and PARRISH, J.M., 1989b, Sedimentology and paleontology of the Upper Triassic Chinle Formation, Bedrock, Colorado: Mountain Geologist, v. 26, p. 113-126.

DuBIEL, R.F., and SKIPP, G., 1989, Sedimentological and stratigraphic studies of the Upper Triassic Chinle Formation, western Colorado: U.S. Geological Survey Open-File Report 89-2, 26 p.

DuBIEL, R.F., in press, Sedimentology and depositional history of the Upper Triassic Chinle Formation in the Uinta-Piceance and Eagle basins, northwestern Colorado and northeastern Utah: U.S. Geological Survey Bulletin 1787, $40 \mathrm{p}$.

Ekdale, A.A., Bromley, R.G., and Pemberton, S.G., 1984, Ichnology-the use of trace fossils in sedimentology and stratigraphy: Society of Economic Paleontologists and Mineralogists, Short Course Notes no. 15, $317 \mathrm{p}$.

Ekstrand, E.J., and ButLER, R.F., 1989, Paleomagnetism of the Moenave Formation: Implications for the Mesozoic North American apparent polar wander path: Geology, v. 17, p. 245-248.

EsPenshade, E.E.B., and Morrison, J.L., eds., 1978, Goode's World Atlas: Rand McNally and Co., Chicago, 372 p.

FLOHN, H., 1968, Contributions to a meteorology of the Tibetan Highland: Atmospheric Science Paper 130, Fort Collins, Colorado, Department of Atmospheric Science, Colorado State University, $120 \mathrm{p}$.

Francis, J.E., 1983, The dominant conifer of the Jurassic Purbeck Formation, England: Paleontology, v. 26, p. 277-294.

Francis, J.E., 1986, Growth rings in Cretaceous and Tertiary wood from Antarctica and their paleoclimatic implications, Paleontology, v. 29, p. 665-684.

FriTTs, H.C., 1976, Tree rings and climate: Academic Press, London, $567 \mathrm{p}$.

GLENNIE, K.W., 1987, Desert sedimentary environments, present and past-a summary: Sedimentary Geology, v. 50, p. 135-165.

GooD, S.C., 1989a, Nonmarine mollusca in the Upper Triassic Chinle Formation and related strata of the Western Interior: in LuCAS, S.G., and HunT, A.P., Dawn of the Age of Dinosaurs in the American Southwest: New Mexico Museum of Natural History, 1989 Spring Field Conference Guidebook, p. 233-248.

Good, S.C., 1989b, Growth banding in fresh water bivalves (Family Unionidae) from the Upper Triassic Chinle Formation of Arizona and New Mexico: Geological Society of America, Abstracts with Programs, v. 21, p. A340.

Good, S.C., Parrish, J.M., and Dubiel, R.F., 1987, Paleoenvironmental implications of sedimentology and paleontology of the Upper Triassic Chinle Formation, southeastern Utah: inCAMPBELl, J.A., ed., Geology of Cataract Canyon and Vicinity: Four Corners Geological Society, Tenth Field Conference Guidebook, p. 117-118.

Good, S.C., PARrish, J.M., and Dubiel, R.F., 1988, Sedimentology and paleontology of the Upper Triassic Chinle Formation, Bedrock, Colorado: Geologic Society of America, Abstracts with Programs, v. 20, p. A268.

GoRDon, W.A., 1975, Distribution by latitude of Phanerozoic evaporite deposits: Journal of Geology, v. 83, p. 671-684.

GotTeSFELD, A.S., 1972, Paleoecology of the lower part of the Chinle Formation in the Petrified Forest: in BREED, C.S., and BREED, W.J., eds., Investigations in the Triassic Chinle Formation: $\mathrm{Mu}$ seum of Northern Arizona Bulletin 47, 59-74.
GRIER, N.M., 1922, Observations on the rate of growth of the shell of lake dwelling freshwater mussels: American Midland Naturalist, v. 8, p. $129-148$.

HABERLe, R.M., 1986, The climate of Mars: Scientific American, v. 254 , p. $54-62$.

Hahn, D.G., and Manabe, S., 1975, The role of mountains in the South Asian monsoon circulation: Journal of Atmospheric Science, v. 32 , p. $1515-1541$.

HANLEY, J.H., 1976, Paleosynecology of nonmarine Mollusca from the Green River and Wasatch Formations (Eocene), southwestern Wyoming land northwestern Colorado: in SCOTT, R.W., and WEST, R.R., Structure and Classification of Paleocommunities: Dowden, Hutchinson, and Ross, Inc., p. 235-261.

Hasiotis, S.T., and Mitchell, C.E., 1989, Lungfish burrows in the Upper Triassic Chinle and Dolores Formations, Colorado Plateau: New evidence suggests origin by a burrowing decapod crustacean: Discussion: Journal of Sedimentary Petrology, v. 59, p. 871-875.

Hay, W.W., Behensky, J.F., Barron, E.J., and Sloan, J.L., 1982, Late Triassic-Liassic paleoclimatology of the proto-central North Atlantic rift system: Palaeogeography, Palaeoclimatology, Palaeoecology, v. 40, p. 13-30.

HoLT, E.L., 1947, Upright trunks of Neocalamites from the Upper Triassic of western Colorado: Journal of Geology, v. 55, p. 511513.

KIETZKe, K. 1989, Calcareous microfossils from the Triassic of the southwestern United States: in LuCAs, S.G., and HunT, A.P., Dawn of the Age of Dinosaurs in the American Southwest: New Mexico Museum of Natural History, 1989 Spring Field Conference Guidebook, p. 223-232.

KLimetz, M.P., 1983, Speculations on the Mesozoic plate tectonic evolution of eastern China: Tectonics, v. 2, p. 139-166.

KNox, R.A., 1987, The Indian Ocean: Interaction with the monsoon: in Fein, J.S., and Stephens, P.L., eds., Monsoons: John Wiley and Sons, New York, p. 365-397.

Krishnamurti, T.N., and Ramanathan, Y., 1982, Sensitivity of the monsoon on set to differential heating: Journal of the Atmospheric Sciences, v. 39, p. 1290-1306.

KutZBaCh, J.E., and GaLlimoRe, R.G., 1989, Pangaean climates: Megamonsoons of the megacontinent: Journal of Geophysical Research, v. 94, p. 3341-3357.

LANGSton, W.W., 1963, Fossil vertebrates and the Late Paleozoic red beds of Prince Edward Island: National Museum of Canada Bulletin, v. 187, p. 1-36.

LiTwin, R.J., 1985, Fertile organs and in situ spores of ferns from the Late Triassic Chinle Formation of Arizona and New Mexico, with discussion of the associated dispersed spores: Review of Paleobotany and Palynology, v. 44, p. 101-146.

LiTwIN, R.J., 1986, The palynostratigraphy and age of the Chinle and Moenave Formations, southwestern U.S.A.: PhD Dissertation, Pennsylvania State University, 282 p.

Lutz, R.A., and RHoADs, D.C., 1980, Growth patterns within the molluscan shell: in RHOADS, D.C., and LUTZ, R.A., Skeletal Growth Aquatic Organisms: Plenum Press, New York, p. 203-254.

MAY, S.R., and BUTLER, R.F., 1986, North American Jurassic apparent polar wander: Implications for plate motion, paleogeography and Cordilleran tectonics: Journal of Geophysical Research, v. 91, p. 11,519-11,544.

McAllister, J.A., 1988, Lungfish burrows in the Upper Triassic Chinle and Dolores Formations, Colorado Plateau: Discussion-comments on the recognition criteria of fossil lungfish burrows: Journal of Sedimentary Petrology, v. 58, p. 365-369.

McCABE, P.J., 1986, Depositional environments of coal and coalbearing strata: in RAHMANI, R.A., AND FloRES, R.M., eds., Sedimentology of coal and coal-bearing sequences: International Association of Sedimentologists, Special Publication 7, p. 13-42.

McElhinny, M., Embleton, B.J.J., MA, X.H., and ZhanG, Z.K., 1981, Fragmentation of Asia in the Permian: Nature, v. 293, p. 212-216.

MCKEE, E.D., 1959, Interval C-Southwest region: in MCKEE, E.D., Oriel, S.S., Ketner, K.B., MacLachlan, M.E., Goldsmith, J.W., 
MacLachlan, J.C., and Mudge, M.R., Paleotectonic Maps of the Triassic System: U.S. Geological Survey, Miscellaneous Geologic Investigations Map I-300, p. 13-14.

MCKeE, E.D., 1979, Introduction to a study of global sand seas: A study of global sand seas: U.S. Geological Survey Professional Paper 1052, p. 1-19.

McMichaEL, D.F., 1952, The shells of rivers and lakes, I: Australian Museum Magazine, v. 10, p. 348-352.

Mohr, E.C.J., VAN BAREN, F.A., and VAN Schuylenborgh, J. 1972, Tropical soils: The Hague, Netherlands, Mouton-Ichtiar Baruvan Hoeve, $480 \mathrm{p}$.

MiURAKami, T., 1987, Orography and monsoons: in Fein, J.S., and STEPHENS, P.L., eds., Monsoons: John Wiley and Sons, New York, p. 331-364.

NEGUS, C.L., 1966, A quantitative study of the growth and production of unionid mussels in the River Thames at Reading: Journal of Animal Ecology, v. 35, p. 513-532.

OLSEN, P.E., 1986, A 40-million-year record of early Mesozoic orbital climatic forcing: Science, v. 234, p. 842-848.

PARRISH, J.M., 1986, Patterns of diversity in the Late Triassic: Comparisons of the Carnian-Norian and Triassic-Jurassic events: Fourth North American Paleontology Convention, Boulder, Colorado, Abstracts with Programs, p. A34.

PARRISH, J.M., 1989, Vertebrate paleoecology of the Chinle Formation (Late Triassic) of the Southwestern United States: Palaeography, Palaeoclimatology, Palaeoecology, v. 72, p. 227-247.

PARRISH, J.M., and GooD, S.C., 1987, Preliminary report on vertebrate and invertebrate fossil occurrences, Chinle Formation (Upper Triassic), southeastern Utah: in CAMPBELL, J.A., ed., Geology of Cataract Canyon and Vicinity: Four Corners Geological Society, Tenth Field Conference Guidebook, p. 109-115.

Parrish, J.M., Parrish, J.T., and Ziegler, A.M., 1986, PermianTriassic paleogeography and paleoclimatology and implications for therapsid distributions: in HoTTON, N.H., III, MACLEAN, P.D., Rotн J.J., and Roth, E.C., The Biology and Ecology of Mammallike Reptiles: Smithsonian Press, Washington, D.C., p. 109-132.

PARRISH, J.T., 1985, Latitudinal distribution of land and shelf and absorbed radiation during the Phanerozoic: U.S. Geological Survey, Open-File Report 85-31, 21 p.

PARRISH, J.T., 1988, Pangaean paleoclimates: EOS, v. 69, p. 1061.

PARRISH, J.T., and CuRTis, R.L. 1982, Atmospheric circulation, upwelling and organic-rich rocks in the Mesozoic and Cenozoic eras: Paleogeography, Paleoclimatology, and Paleoecology, v. 40, p. 3166.

PARRISH, J.T., and Doyle, J.A., 1984, Predicted evolution of global climate in Late Jurassic-Cretaceous time: International Organization of Paleobotany Conference, Abstracts.

PARRISH, J.T., and Peterson, F., 1988, Wind directions predicted from global circulation models and wind directions determined from eolian sandstones of the western United States-a comparison: Sedimentary Geology, v. 56, p. 261-282.

Parrish, J.T., and SPICER, R.A. 1988, Middle Cretaceous wood from the Nanushuk Group, central North Slope, Alaska: Paleontology, v. 31, p. $19-34$.

PARRish, J.T., Ziegler, A.M., and Scotese, C.R., 1982, Rainfall patterns and the distribution of coals and evaporites in the Mesozoic and Cenozoic: Palaeogeography, Palaeoclimatology, and Palaeoecology, v. 40, p. 67-101.

Peterson, F., 1988, Pennsylvanian to Jurassic eolian transportation systems in the western United States: Sedimentary Geology, v. 56 , p. $207-260$.

Pindell, J., and Dewey, J.F., 1982, Permo-Triassic reconstruction of western Pangaea and the evolution of the Gulf of Mexico/ Caribbean region: Tectonics, v. 1, p. 179-211.

RAMAGE, C.S., 1966, The summer atmospheric circulation over the Arabian Sea: Journal of the Atmospheric Sciences, v. 23, p. 144150.

RAMAGE, C.S., 1971, Monsoon meteorology: International Geophysical Series 15, Academic Press, New York, 296 p.
RoBInson, W.I., 1915, Two new freshwater gastropods from the Mesozoic of Arizona: American Journal of Science, v. 40, p. 649-651. RoBINSON, P.L., 1973, Paleoclimatology and continental drift: in TARLING, D.H., and RUNCORN, S.K., eds., Implications of Continental Drift to the Earth Sciences, I: Academic Press, London, p. 449476.

Rowley, D.B., Raymond, A., Parrish, J.T., Lottes, A.L., Scotese, C.R., and ZIEGLER, A.M., 1985, Carboniferous paleogeographic, phytogeographic, and paleoclimatic reconstructions: International Journal of Coal Geology, v. 5, p. 7-42.

RumNey, G.R., 1968, Climatology and the world's climates: New York, Macmillan, $656 \mathrm{p}$.

SchaEfFER, B., 1967, Late Triassic fishes from the Western United States: Bulletin of the American Museum of Natural History, v. 135 , p. 287-342.

SchulTz, L.G., 1963, Clay minerals in Triassic rocks of the Colorado Plateau: U.S. Geological Survey Bulletin 1147-C, C1-C47.

Schwartz, H., and GilletTE, D.D., 1986, Microstratigraphy and sedimentology of the Coelophysis Quarry, (Upper Triassic, Chinle Formation) at Ghost Ranch, Abiquiu, New Mexico: Fourth North American Paleontological Convention, Boulder, Colorado, Abstracts with Programs, p. A41.

SchwarzBaCH, M., 1963, Climates of the past-an introduction to paleoclimatology: London, C. Van Nostrand Co., Ltd., 328 p.

Scotese, C.R., BaMBaCh, R.K., Barton, C., VAN DER Voo, R., and ZIEGLER, A.M., 1979, Paleozoic base maps: Journal of Geology, v. 87 , p. $217-277$.

SimMs, M.J., and RUFFELL, A.H., 1989, Synchroneity of climatic change and extinctions in the Late Triassic: Geology, v. 17, p. 265-268.

Simms, M.J., and Ruffell, A.H., in press, Climatic and biotic change in the Late Triassic: Journal of the Geological Society of London.

Smith, A.G., Briden, J.C., and Drewry, G.E., 1973, Phanerozoic world maps: in Hughes, N.F., ed., Organisms and Continents through Time: Special Paper of the Paleontological Association 12 , p. $1-42$.

Smith, A.G., and Briden, J.C., 1977, Mesozoic and Cenozoic paleocontinental maps: Cambridge, Cambridge University Press, $63 \mathrm{p}$.

SPICER, R.A., and PARRISH, J.T., 1990, Late Cretaceous-Early Tertiary paleoclimates of northern high latitudes-A quantitative view: Journal of the Geological Society of London, v. 147, p. 329-341.

Stansbery, D.H., 1961, The naiades (Mollusca, Pelecypoda, Unionacea) of Fishery Bay, South Bass Island, Lake Erie: Sterkiana, v. 5, p. 1-37.

Stewart, J.H., Poole, F.G., and Wilson, R.F., 1972, Stratigraphy and origin of the Chinle Formation and related Upper Triassic strata in the Colorado Plateau region: U.S. Geological Survey Professional Paper 690, 336 p.

StewarT, J.H., ANDERson, T.H., HaXel, G.B., Silver, L.T., and WRIGHT, J.E., 1986, Late Triassic paleotopography of the southern Cordillera: The problem of a source area for voluminous volcanic detritus in the Chinle Formation of the Colorado Plateau region: Geology, v. 14, p. 567-570.

Sues, H-D., and Olsen, P.E., 1990, Triassic vertebrates of Gondwanan aspect from the Richmond basin of Virginia: Science, $v$. 249 , p. $1020-1023$.

Tevesz, M.J., and CarTer, J.G., 1980a, Environmental relationships of shell form and structure of Unionacean bivalves: in RHOADS, D.D., and LuTz, R.A., Skeletal Growth of Aquatic Organisms: Plenum Press, New York, p. 295-322.

Tevesz, M.J., and CARTER, J.G., 1980b, Study of annual growth bands in Unionacean bivalves: in RHOADs, D.C., and LUTZ, R.A., Skeletal Growth of Aquatic Organisms: Plenum Press, New York Appendix 1, Part 4, p. 613-614.

Turner, P., 1980, Continental red beds: Developments in Sedimentology 29: Elsevier, Amsterdam, 562 p.

VaIL, P.R., Mitchum, R.M., Jr., and Thompson, S., III, 1977, Global cycles of relative sea level change: Seismic stratigraphy-applications to hydrocarbon exploration: American Association of $\mathrm{Pe}$ troleum Geologists Memoir 26, p. 83-97. 
VALENTINE, J.W., and MooREs, E.M., 1970, Plate-tectonic regulation of faunal diversity and sea level: A model: Nature, v. 228, p. $657-$ 659.

VAN Der Voo, R., Mauk, F.J., and French, R.B., 1976, PermianTriassic continental configurations and the origin of the Gulf of Mexico: Geology, v. 4, p. 177-180.

VAUGHN, P.P., 1964, Evidence of estivating lungfish from the Sangre de Cristo Formation, Lower Permian of northern New Mexico: Los Angeles County Museum Contributions to Science, v. 80, p. 1-8.

VEEVERS, J.J., 1988, Gondwana facies started when Gondwana merged in Pangaea: Geology, v. 16, p. 732-734.

Waters, A.C., and Granger, H.C., 1975, Volcanic debris in uraniferous sandstones and its possible bearing on the origin and precipitation of uranium: U.S. Geological Survey Circular 224, 26 p.

W Augh, B., 1973, The distribution and formation of Permian-Triassic red beds: in Logan, A., and HiLls, L.V., eds., The Permian and Triassic Systems and Their Mutual Boundary: Canadian Society of Petroleum Geologists Memoir 2, p. 678-693.

WeBster, P.J., 1981, Monsoons: Scientific American v. 245, p. 108118.

WeBSTER, P.J., 1987, The elementary monsoon: in FEIN, J.S., and StePhens, P.L., eds., Monsoons: John Wiley and Sons, New York, p. 3-32.

WEBSTER, P.J., Chou, L., and LAU, K.M., 1977, Mechanisms effecting the state, evolution and transition of the planetary scale monsoon: Pure and Applied Geophysics, v. 115, p. 1463-1491.

WITTE, W.K., and KENT, D.V., 1989, A middle Carnian to early Norian ( $\sim 225 \mathrm{Ma})$ paleopole from sediments of the Newark Basin, Pennsylvania: Geological Society of America Bulletin, v. 101, p. 11181126.

WITTE, W.K., and KENT, D.V., 1990, The paleomagnetism of red beds and basalts of the Hettangian extrusive zone, Newark Basin, New Jersey: Journal of Geophysical Research, v. 95, p. 17,533-17,545.

YounG, A., 1976, Tropical soils and soil survey: Cambridge University Press, Cambridge, $468 \mathrm{p}$.

YounG, J.A., 1987, Physics of monsoons: the current view: in FeIN, J.S., and Stephens, P.L., eds., Monsoons: John Wiley and Sons, New York, p. 211-243.

Ziegler, A.M., Scotese, C.R., and Barrett, S.F., 1983, Mesozoic and Cenozoic paleogeographic maps: in BROSCHE, P., and SUNDERMANN, J., eds., Tidal friction and the earth's rotation. II: SpringerVerlag, Berlin, p. 240-252.

Ziegler, A.M., Scotese, C.R., McKerrow, W.S., Johnson, M.E., and BАмвACH, R.K., 1979, Paleozoic paleogeography: Annual Review of Earth and Planetary Sciences, v. 7, p. 473-502.

ACCEPTED APRIL 2, 1991 